\title{
Drugs That Changed Society: History and Current Status of the Early Antibiotics: Salvarsan, Sulfonamides, and $\beta$-Lactams
}

\author{
Søren Brogger Christensen
}

check for updates

Citation: Christensen, S.B. Drugs That Changed Society: History and Current Status of the Early Antibiotics: Salvarsan, Sulfonamides, and $\beta$-Lactams. Molecules 2021, 26 , 6057. https://doi.org/10.3390/ molecules26196057

Academic Editor: Manuel Simões

Received: 15 August 2021

Accepted: 29 September 2021

Published: 7 October 2021

Publisher's Note: MDPI stays neutral with regard to jurisdictional claims in published maps and institutional affiliations.

Copyright: (C) 2021 by the author. Licensee MDPI, Basel, Switzerland. This article is an open access article distributed under the terms and conditions of the Creative Commons Attribution (CC BY) license (https:// creativecommons.org/licenses/by/ $4.0 /)$.
The Museum of Natural Medicine \& The Pharmacognostic Collection, University of Copenhagen, Jagtvej 162, DK-2100 Copenhagen, Denmark; soren.christensen@sund.ku.dk; Tel.: +45-3533-6253

\begin{abstract}
The appearance of antibiotic drugs revolutionized the possibilities for treatment of diseases with high mortality such as pneumonia, sepsis, plaque, diphtheria, tetanus, typhoid fever, and tuberculosis. Today fewer than $1 \%$ of mortalities in high income countries are caused by diseases caused by bacteria. However, it should be recalled that the antibiotics were introduced in parallel with sanitation including sewerage, piped drinking water, high standard of living and improved understanding of the connection between food and health. Development of salvarsan, sulfonamides, and $\beta$-lactams into efficient drugs is described. The effects on life expectancy and life quality of these new drugs are indicated.
\end{abstract}

Keywords: bacterial infectious diseases; salvarsan; sulfonamides; penicillins; cephalosporins; carbapenems; thiopenems; monobactams; $\beta$-lactamases

\section{Introduction}

Infectious or communicative diseases have been a severe burden for mankind for millennia. The absence of knowledge of the pathogen organisms prevented prophylaxis and treatment of the maladies until the early 21st century. In Denmark, an overview of morbidity reveals that in the period 1876-1880 communicative diseases were the cause of almost 3/4 (72\%) of mortality, in the period 1900-1903 almost half the deaths (42\%), in 1920 about a $1 / 7(15 \%)$, in 1945 only $4 \%$ and in 2013 only $0.5 \%$ [1,2]. The abrupt fall in death rate of communicative infections was caused by sanitation, higher living standards and introduction of efficient drugs as will be explained below. Bacteria were described as animalcules already in 1683 by the Dutch merchant Leeuwenhoeck [3,4]; but the importance of the discovery was not realized until 200 years later. Several different microorganisms were described and depictured by a Danish scientist Müller in the atlas Animalcula infusoria fluviatilia et marina (1786) [5]. The first correlation between microorganisms and health came in 1836 when the Italian civil servant Bassi described that a minute fungus (Botrytis bassina) was fatal to silkworms. The German clinician Shönlein realized in 1839 that the pathogen causing the human skin disease favus was a fungus (Achorion schöleinii). Some scientists proposed in the 1830s that fermentation was a conversion of organic compound performed by living microorganisms (yeast). However, leading chemists such as Berzelius and Liebig suggested that fermentation was a purely chemical process [3]. In 1873, Pasteur published a study on the diseases of the vine revealing that in the microscope he could see two organisms on the surface of the peel of grapes, some small organisms and some big organisms. By heating the grapes to $80^{\circ} \mathrm{C}$ the small organisms were killed but the big survived. This later has been called Pasteurization [6]. Today the small organisms are known as bacteria and the big organisms as yeast. Another important contribution of Pasteur was the demonstration that life does not evolve spontaneously. Development of life in uninfected media was demonstrated to originate from germs present in the air. In 1849, Davaine demonstrated the presence of Bacillus anthracis in the blood of cattle suffering from anthrax. This was the first mammalian disease for which a bacterium was shown to be the pathogenic organism. Pasteur showed in 1877 
that transfer of blood from an infected animal to a healthy animal communicates the disease. Pasteur also realized that virulence of the anthrax bacteria could be attenuated by cultivation at high temperature. Inoculation in animals with the attenuated organism protected the animal from developing disease. The technique of decreased virulence was used for prevention of rabies in a boy bitten by a mad dog. In 1882 Koch discovered the tubercle bacterium (Mycobacterium tuberculosis). The studies of Pasteur and Koch formed the foundation of bacteriology as we know it today [3]. After these pioneering studies several pathogenic bacteria were characterized, Corynebacterium diphteriae (diphtheria) Pasteurella pestris (plague), Clostridium tetani (tetanus), Salmonella typhosa (typhoid fever), and Mycobacterium tuberculosis (tuberculosis). In 1900, pathogenic organisms causing 21 diseases were discovered [3]. A late discovery of new pathogenic agents was made in 1983 when bacteria were discovered in the stomach of patients suffering from gastritis and peptic ulceration [7,8]. The bacteria later were identified as Campylobacter pyloridis [9]. The discovery was met with some skepticism, since it was difficult to accept that bacteria could live in the hostile environment of the stomach [10]. In 2008, Warren and Marshall were awarded the Nobel Price for their discovery of the pathogenic properties of what today is known as Helicobacter pylori [10]. In 2001, several 1425 infectious organisms were known, including 217 virus and prions, 538 bacteria, 307 fungi, 66 protozoa, and 287 helminths [11].

The importance of hygiene for life expectancy was gradually understood in the last part of the 19th century. The ideal man in Greek/Roman philosophy was healthy and beautiful. To obtain a beautiful body, public baths were needed. Aquaducts provided fresh and clean water and public latrines were used. Sewers (cloacae) build in the 6th century B.C. are still a part of the Roman sewerage. According to Christianity, the body is just the holster for the soul and consequently needed no attention [12]. After the fall of the Roman Empire in the 5th century A.D., hygiene in Europe declined. In contrast, it was to some extent maintained in Medieval Muslim Europe [13]. Urbanization as a consequence of industrialization afforded metropoles with poor hygiene. Two major cholera outbreaks (1848-1849 and 1865-1867) encouraged sanitation. Construction of sewerages in most major European cities were completed in the last decade of the 19th century [13]. It soon was realized that dumping of the superfluous water and filth in rivers or seas caused unacceptable contamination. Consequently biological filters were installed in the early 21st century [13]. Sanitation was a time consuming project, even in the 1970s apartments with shared latrines in the backyard with no drainage could still be found in Copenhagen and probably also in other European cities. It is encouraging to realize that the construction of sewerage was initiated after the big cholera epidemics, but before it was established that the cholera bacteria (Vibrio cholerae) was the pathogenic organism 1883 [3]. Supply of clean piped water in general developed slower since this very often was constructed by private enterprises [13,14]. In northern Europe most cities had piped water in 1915 and most cities in southern Europe in 1940. Later the importance of higher standards of living and proper food has been realized [3].

The effect of sanitation is clearly revealed by the abrupt fall in mortality caused by infectious diseases in the period 1875 to 1920 . However, one infectious disease remained unaffected: syphilis [1]. Efficient therapy for bacterial diseases slowly started to appear in the second decade of the 20th century but the breakthrough came when sustainable production of penicillin was invented in the 1940s. The naturally occurring $\beta$-lactams afforded access to efficient antibiotic drugs [15-17]. The term chemotherapy was introduced by Ehrlich. It was defined as the use of drugs to injure an invading organism without injure to the host [18]. Later antibiotics were defined as compounds combating invading organisms [19]. Today the term chemotherapeutics is mainly used for drugs curing cancer diseases, in contrast to the original definition of Ehrlich. Antibiotics are drugs curing infectious diseases, irrespectively of natural or synthetic origin. The years from about 1940 to 1960 were the golden age of antibiotics. In this period most of the antibiotic classes used today were introduced. Emerging resistance toward antibiotics, however, becomes an increasing threat. In 2012, the Congress of the USA passed legislation for antibiotic 
development. In 2014, president Obama issued an order for substantial government intervention to stimulate infectious disease research and drug development [20]. Not all bacteria are hostile. An intact intestinal microbiota affords and important protection against pathogenic bacteria. Antibiotics should be used with care to prevent corruption of the intestinal flora [21]. The difference between antibiotics and vaccination (Section 9) is that the former only cure a disease, whereas the latter primarily prevents infection.

\section{Arsphenamine (Salvarsan)}

The number of deaths of communicative diseases dramatically decreased in the period from 1875 to 1903 . In contrast, the morbidity of syphilis remained approximately $0.2 \%$ of all deaths in Denmark [1]. Syphilis, "the terror of the early 20th century [22]", was a heavy burden in other parts of Europe, with 1/6 of all Parisians and 1/10 of all Londoners infected [22]. The first efficient drug was based on a wrong but fruitful working hypothesis made by Paul Ehrlich: "Some dyes specifically color some organs and microorganisms. Consequently, these dyes can be used for selective targeting these organs or organisms." Based on this observation Ehrlich concluded that a magic bullet (die magische Kugel) can be designed. The magic bullet enables selective killing of microorganisms or cancer cells. Ehrlich tested several compounds for their ability to cure syphilis infected mice. In 1909, compound 606, arsphenamine or salvarsan (Figure 1) turned out to have an effect. Already a year later positive clinical results were published [23]. The synthetic path for preparation of arsphenamine occasionally resulted in toxic contaminants [24]. Thus, after only a few decades the drug was displaced with the safer penicillin [22]. In most databases and textbooks arsphenamine is depicted as 1a (Figure 1). However, ESI MS has revealed that the molecule is a mixture of cyclic compounds $\mathbf{1 b}$, with different numbers of arsenic atoms in the ring. The dominating molecules are trimers of 4-hydroxy-3-aminophenylarsen (1) $\mathrm{n}=1$ ) and pentamers $(\mathrm{n}=3)$, but also tetramers, hexamers and heptamers (n equals 2, 4 and 5) are present [24]. Arsphenamine was marketed as salvarsan. Poor aqueous solubility of arsphenamin was overcome by preparation of neosalvarsan, for which the structure $2 \mathbf{a}$ has been suggested [18]. Later studies suggested that the cyclic arsenicals only are prodrugs of the active warhead osphenarsine 3 [24]. Arsphenamine was the first marketed antibiotic, which cured an infectious disease caused by bacteria [25]. For a period until the 1940s, oxphenarsine (3) replaced salvarsan under the tradename Mapharsen until only penicillin was used for treatment of syphilis [18].<smiles>[R]Nc1cc(C=[As]c2ccc(O)c(N)c2)ccc1O</smiles>

1a $\mathrm{R}=\mathrm{H}$

2a $\mathrm{R}=-\mathrm{CH}_{2}-\mathrm{SO}_{2}-\mathrm{Na}^{+}$

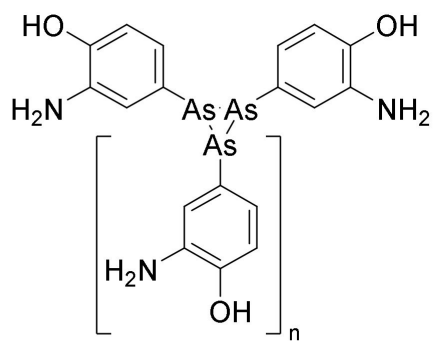

1b<smiles>Nc1cc([As]=O)ccc1O</smiles>

3

Figure 1. The commonly shown structure for arsphenamine (salvarsan) is 1a. Arsphenamine is now known to be a mixture of compounds with the formula $\mathbf{1 b}$, in which $\mathrm{n}$ varies from 1 to 7 . The predominant values are $\mathrm{n}=1$ and $\mathrm{n}=3$. Neosalvarsan (2a) was designed to increase the solubility [18]. Oxphenarsine 3 is the expected active metabolite of arspehamine [24].

Arspehnamine was not the first example of a magic bullet, quinine used for the treatment of malaria had been known for almost a century [26]. 


\section{Sulfonamides}

\subsection{Discovery}

Ehrlich's idea of a magic bullet inspired G. Domagk to test several hundred compounds. Azo compounds gave promising results when tested on mice infected with streptococci, but were inactive in vitro [27]. On December 20, 1932 prontosil (Figure 2, 4) was shown to prevent mice and rabbits from dying of a lethal infection of Streptococcus [28]. Soon after filing of the patent clinical studies were performed. Patients suffering from infections with Streptococcus were treated. Encouraging positive results were obtained in most cases, although severe infections did not respond satisfactory [29,30]. Domagk's daughter at six years of age developed a life threatening infection, which in a miraculous way was cured by administration of prontosil [22]. The compound developed into a blockbuster for I. G. Farben, at which Domagk was employed. In 1935 the sale of Prontosil totaled 175,000 marks, 1936 the sale rose to about 1 million marks and in 1937 more than 5 million marks [27]. Soon the drug was introduced to the world. It was considered a "miracle drug". Since German patents were not recognized in France, an independent production was made in this country under the name of rubiazol. A side effect was that the skin of some patients became reddish. Fortunately this effect was temporary. The introduction of the sulfa drugs was a turning point in treatment of streptococcal diseases such as childbed fever and septicemia, pneumonia, meningitis, dysentery, gonorrhea, and urinary tract infections [27]. Already in 1939, Domagk was offered the Nobel Price, but the situation in Germany prevented him from receiving it until 1947 [22].<smiles>Nc1ccc(N=Nc2ccc(S(N)(=O)=O)cc2)c(N)c1</smiles><smiles>Nc1ccc(S(N)(=O)=O)cc1</smiles><smiles>Nc1ccc(S(=O)(=O)Nc2ccccn2)cc1</smiles>

Figure 2. Prontosil (4), sulfonamide (4-aminobenzenesulfonamiode, 5) and 4-sulfapyridine (6).

By accident Bovet's group in 1935 tested 4-aminobenzenesulfamide (sulfanilamide, 5) for treatment of streptococcal infections in rabbits. To their surprise and disappointment 5 was as efficient as prontosil. However, some reflections led to the conclusion that the discovery of a simple but efficient molecule opened the possibilities for designing new simple antibiotics [31]. Shortly thereafter a new study revealed that in contrast to prontosil 4 -aminobezenesulfonamide inhibits the growth of bacteria in vitro and is efficient for treatment of streptococcal infections in man [32]. It is now accepted that prontosil (4) is a prodrug for 4-aminobenzenesulfonamide (5) formed by reductive cleavage of the $\mathrm{N}=\mathrm{N}$ double bond [33].

In 1938, May and Baker marketed 4-sulfapyridine (6) as the first sulfa drug, which could cure "captain of the death" bacterial pneumonia. In late 1943 Winston Churchill suffered from a potentially lethal pneumonia. The infection was miraculously cured by 4-sulfapyridine (6), a sale promoting event [27]. The introduction of sulfa drugs for treatment of infections revolutionized treatment of streptococcal infections in the early 20th century [34]. The introduction of penicillin decreased the demand for sulfa drugs [27].

\subsection{Mechanism of Action}

If bacteria are incubated with yeast extract containing 4-aminobenzoate and sulfanilamide (5) the growth inhibition is antagonized (Scheme 1, 8) [35]. This discovery led to understanding of the mechanism of action of sulfanilamide. Tetrahydrofolate (10) is formed from the building blocks 7,8-dihydropteridinepyrophosphate (7) and 4-aminobenzoic acid (8) in bacteria [36]. Sulfonamide (Figure 3, 5) interacts with dihydropteroate synthase and prevents formation of tetrahydrofolate (10). If sufficient 4-aminobenzoate is present sulfonamide will be displayed from the enzyme neutralizing the inhibition. Tetrahydrofolate (10), 
a precursor for folic acid, is a vitamin for mammalian [37]. Consequently, administration of an antimetabolite of 4-aminobenzoic acid (8) does not affect mammalian cells. If no other targets for sulfanilamide than the tetrahydrofolate existed, the compound would be harmless for mammalians, whereas it is a potent proliferation toxin for microorganisms.<smiles>Nc1ccc(C(=O)O)cc1</smiles><smiles>Nc1nc(=O)c2c([nH]1)NCC(CNc1ccc(C(=O)N[C@@H](CCC(=O)O)C(=O)O)cc1)N2</smiles>

10<smiles></smiles>

Scheme 1. Biosynthesis of tetrahydrofolate (10) from 7,8-dihydropteridinepyrophosphate (7) and 4-aminobenzoic acid (8) via 7,8-dihydropteroate (9) and dihydrofolate (11) [36]. Dihydropteroate synthase (E1), dihydrofolate synthase (E2) and dihydrofoate reductase (E3) [37].

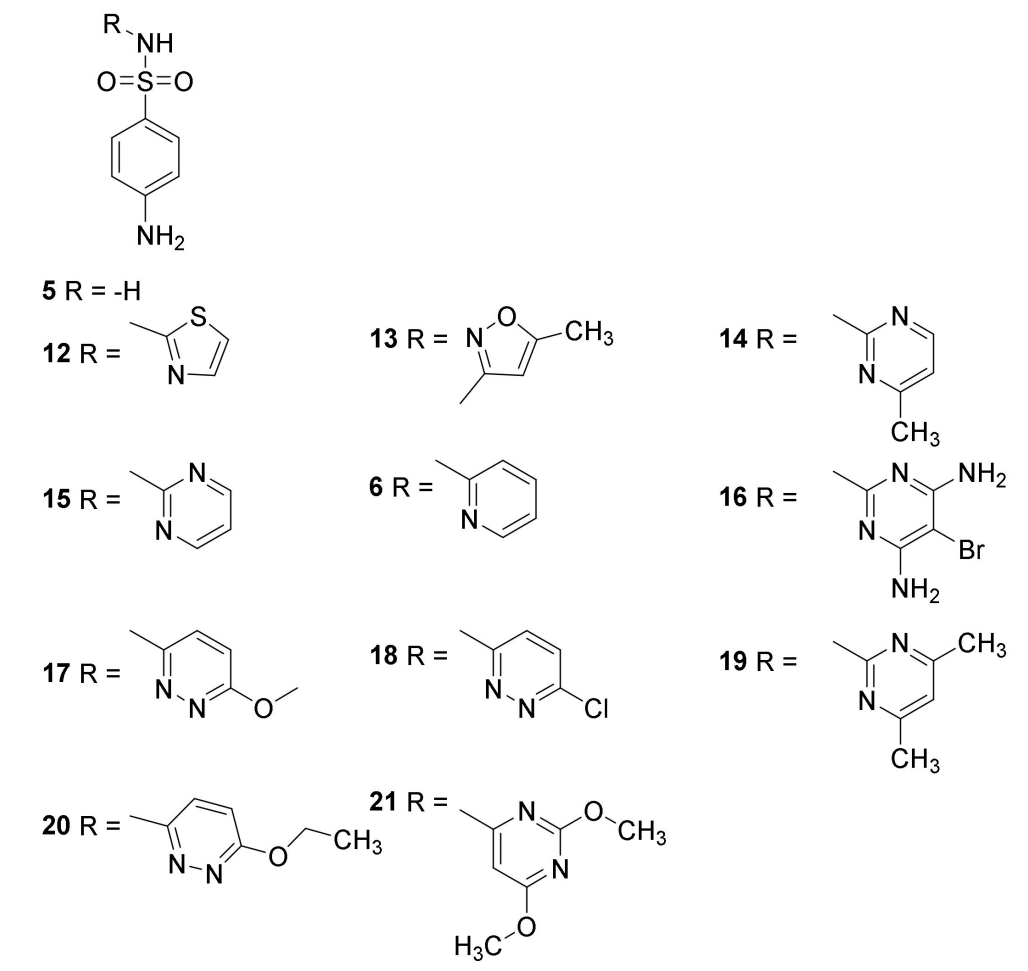

Figure 3. Clinically used sulfonamides for treatment of infectious diseases: sulfonilamide (5), sulfapyridine (6), sulfathiazole (12), sulfamehoxazole (13), sulfamerazine (14), sulfadiazine (15), sulfabromomethazine (16), sulfamethoxypyridazine (17), sulfachloropyridazine (18), sulfametazine (19), sulfaethoxypyridazine (20) and sulfadimethoxine (21) [36]. 
The sulfonamides have two proteolytic groups the sulfonamide with a $\mathrm{pK}_{\mathrm{A}}$ value of 5-8 and the protonated amino group $\mathrm{pK}_{\mathrm{A}} 2-2.5$ [36]. Poor aqueous solubility complicates administration of sulfa drugs. Consequently, they are administered as the more water soluble sodium salts.

Side effects of sulfonamides or accidentals discoveries have led to several drugs possessing the pharmacophore, but with no antibiotic effects. Examples of such drugs are acetazolamide and furosemide (both used as diuretics), glibenclamide (for treatment of diabetes mellitus 2), parecoxib (a COX2 inhibitor) and dofetilide (a class III antiarrhythmic drug) [36].

\section{4. $\beta$-Lactams}

Six ring systems including a $\beta$-lactam ring are found in nature $\beta$-lactams, penams, cephems, clavan, penems or thiopenem and carbapenems (Figure 4) [37]. The clinical use of $\beta$-lactams has revolutionized treatment of infectious diseases [38]. The systematic name for the $\beta$-lactam ring is azetidinone.

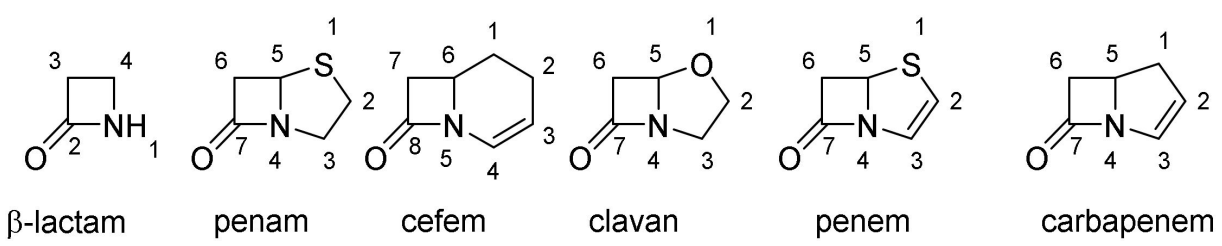

Figure 4. Naturally occurring $\beta$-lactams backbones [37].

\subsection{Discovery of the Penicillins}

If untreated infections with Streptococcus aureus might be fatal. In the first decades of the 20th century, no drug for treatment was known [39]. By accident, studies of the rare mold Penicillium rubrum were performed in laboratories in the vicinity of Flemings laboratory. Some spores appeared on a Petri dish used for growth of Staphylocccus sp. This dish was left by Fleming in his laboratory during a holiday. During his absence an unusually cold period in London favored the growth of $p$. rubrum. When the mold culture was well established, the temperature rose favoring growth of $S$. aureus. Inhibition zones around the mold colonies led Fleming to the conclusion that antibacterial compounds were produced, a simple but far reaching conclusion [22]. The growth of several other bacteria such as Staphylococcus pyrogenes, Streptococcus pyrogenes, Streotococcus viridans, diphteroid bacillus, and Micrococcus lysodeikticus was also inhibited, but not the growth of Bacillus anthracis, Bacillus typhoeus, and enterococcus [40]. In his publication from 1929, Fleming claimed that $p$. rubrum had contaminated his dishes [40]. Later publications, however, mention $p$. notatum [22,41]. Fleming used the broth of $p$. rubrum to cure a severe conjunctivitis in a student [22]. These data, surprisingly, did not call for attention. This situation changed when Florey at the University of Oxford took up the challenge to develop a protocol for large scale production of penicillin. Florey supervised a group consisting of two biochemists Chain and Heatley. Industrial large scale production of penicillin, however, first succeeded when Florey and Chain went to the USA. They constructed 500 gallon tanks, replaced the growth medium with corn steep liquor and found a new Penicillium species $(p$. chrysogenum) producing 100 times more penicillin. These changes enabled production of penicillin in ton scale. By up scaling the equipment to 7500 gallon tanks Pfizer produced 4 tons in 1945 [22,41,42]. The results from the first clinical trials were so impressive that the US army immediately included penicillin in the armamentarium for combating infections in the military hospitals [43]. The US army, being the main sponsor, received all the produced penicillin until the production in 1945 fulfilled the army's demand. The surplus enabled civilians to benefit from the drug. F-pencicllin (Figure 5, 22) and I-dihydropenicilllin (23) were the first isolated natural products possessing the penam nucleus. The N-acyl side chain originates from carboxylic acids in the medium. The phenylacetyl group in G- 
penicllin (24) was introduced after shifting the medium to corn steep liquor [44]. Addition of different carboxylic acids to the medium enables variation of the $N$-acyl group $[42,44]$. Even today after development of sophisticated syntheses for azetidinone the majority of pencillins marketed are made by semisyntheses using starting materials obtained from Penicillium broths $[44,45]$.<smiles>[R]N[C@H]1C(=O)N2[C@H]1SC(C)(C)[C@H]2C(=O)O</smiles>

$22 \mathrm{R}=-\mathrm{CO}-\mathrm{CH}_{2}-\mathrm{CH}=\mathrm{CH}-\mathrm{CH}_{2}-\mathrm{CH}_{3}$

$23 \mathrm{R}=-\mathrm{CO}-\mathrm{CH}_{2}-\mathrm{CH}_{2}-\mathrm{CH}_{2}-\mathrm{CH}_{2}-\mathrm{CH}_{3}$<smiles>[R4][R4]</smiles><smiles>[R16]CC(=O)Cc1ccc(O)cc1</smiles>

$26 \mathrm{R}=-\mathrm{CO}-\mathrm{CH}_{2}-\left(\mathrm{CH}_{2}\right)_{5}-\mathrm{CH}_{3}$

Figure 5. Structures of penicillins with British and American names. Penicillin-I/F-penicillin (22), dihydropenicillin-I (23), penicillin-II/G-penicillin (24), penicillin-III/ X-penicillin (25) and K-penicillin (26). The side chain is dependent on the Pencillium species and broth from which the penicillin is isolated.

In addition to the impressive research performed in UK and USA a small pharmaceutical company in Denmark, Løvens Kemiske Fabrik (today Leo Pharma), succeeded in production of penicillin already in 1943. The prepared penicillin was used in some clinical cases. The late Danish Minister of Foreign Affairs, Per Stig Møller, was cured for pneumonia. Production was shut down in 1944 to prevent the Nazi occupation forces from accessing the strategic valuable drug [46]. After the war, the production was reestablished and the company became an important supplier to the market.

\subsection{Structure Elucidation and Chemistry of Penicillin}

The structure of penicillin was established through several chemical reactions (Schemes 2 and 3) and by X-ray crystallography. The structure was published in two almost identical manuscripts in Nature and Science authored by research groups from several AngloAmerican pharmaceutical companies. From a historical point of view the two publications are instructive examples on structure elucidation before the development of spectroscopy $[47,48]$. In the 1940s, the challenge of elucidating the structure of a crystalline compound with molecular weight of about 350 required enormous intellectual and financial resources as evidenced by the list of contributors to the two manuscripts [47-49]. Hodgkin published an X-ray analysis of a crystalline sodium salt of 22 confirming the previously reported results [50]. Several misleading structures were suggested before the correct structure was established [49]. Today, an average master's student might elucidate the structure in weeks, taking advantage of developed spectroscopy tools. The 2D NMR pulse sequences developed by the recently deceased Nobel laureate Richard R. Ernst in particular has facilitated structure elucidation [49]. 

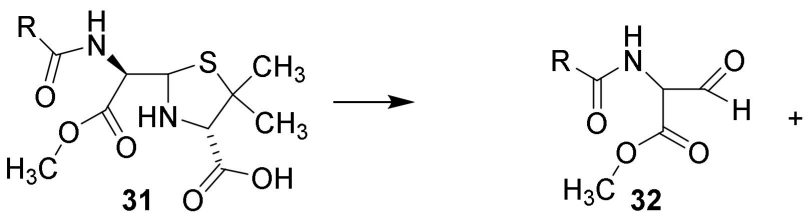<smiles>CC(C)(S)C(N)C(=O)O</smiles><smiles>[R]C(=O)N[C@H]1C(=O)N2[C@@H]1SC(C)(C)[C@H]2C(=O)O</smiles><smiles>CCCCC</smiles><smiles>[R]C(=O)NC(C(=O)O)C(=O)O</smiles><smiles>CC(C)(S)C(N)C(=O)O</smiles><smiles>[Y]C(C)C(=O)N[C@H](C(=O)NCc1ccccc1)[C@@H]1N[C@H](C(=O)[O-])C(C)(C)S1</smiles><smiles>[R]C(=O)NCC=O</smiles>

29

Scheme 2. Structure elucidation of penicillin. Hydrolysis with mineral acid affords carbon dioxide, penicillamine (28) and penaldic acid (27), which is labile and spontaneously converted into penillo-aldehyde (29). Treatment with benzylamine yields aminolysis of the $\beta$-lactam to give the benzylammonium salt of the benzylamide 30. Methanolysis affords the monomethyl ester of methyl penicilloate (31), which may be converted into methyl penaldoate and (32) and penicillamine (28). The suggested structures have been confirmed by syntheses $[47,48]$.

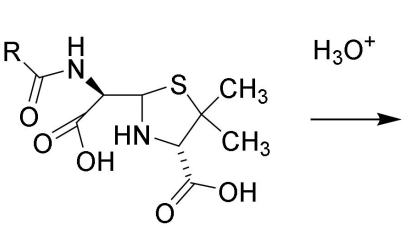

33

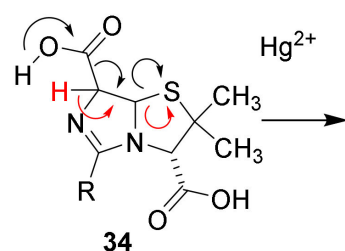

$1 \mathrm{BaSO}_{4}$<smiles>[R]c1nc(C(=O)O)cn1[C@@H](C(=O)O)C(C)(C)S</smiles>

Scheme 3. In aqueous solution pencillin is hydrolyzed (black arrows) to penicilloic acid (33), which rearranges into penillic acid (34). Catalyzed by mercury ions 34 is converted into penillamine (35), or catalyzed by barium sulfate (red arrows) isomerize into isopenicillic acid (36) by a retro Hetero-Michael addition $[47,48]$. 
Tension in the $\beta$-lactam ring causes the lactam to be extremely reactive compared to other amides. The stability of amides is partly explained by the two resonance structures the amide and the zwitterionic structure. Tension in the four-membered lactam ring makes the zwitterionic resonance structure unfavorable (Scheme 4) [45,51]. As a consequence, penicillin reacts freely with alcohols. In penicillin-binding peptides a serine residue in the active site is esterified by the penicillins [52]. Other examples of reactive cyclic amides are known (see Section 9) [53].<smiles>[R]C(=O)NC1C(=O)N2[C@@H](C(=O)O)C(C)(C)S[C@H]12</smiles><smiles>[R]NC(=O)C(CO)N[R]</smiles>

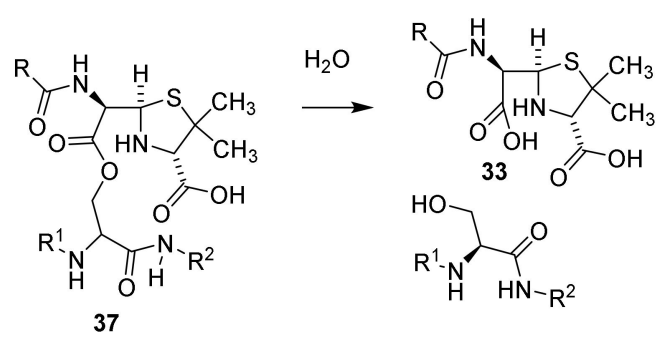

Scheme 4. Resonance of penicillin and reaction with penicillin-binding peptide to acylate the penicillin-binding peptide (37) followed by hydrolysis [45,47,48].

From a biogenetic point of view penicillin is a non-ribosomal peptide originating in the peptide $\zeta$-L-aminoadipidoyl-L-cysteinoyl-D-isovalerine, which by the enzymes isopenicillin $\mathrm{N}$-synthase and isopenicillin $\mathrm{N} \mathrm{N}$-acyltransferase is converted into penicillin G (Scheme 5, 24) [37,54]<smiles>CC(C)[C@H](C(=O)O)N(C(=O)O)C(=O)[C@H](CS)NC(=O)CCC[C@H](N)C(=O)O</smiles>

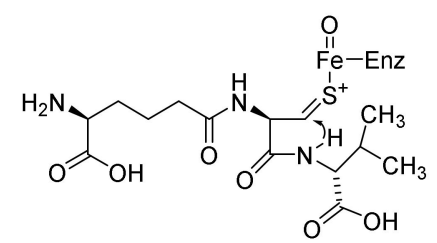<smiles>CC1(C)S[C@@H]2C(NC(=O)CCC[C@H](N)C(=O)O)C(=O)N2[C@H]1C(=O)O</smiles>

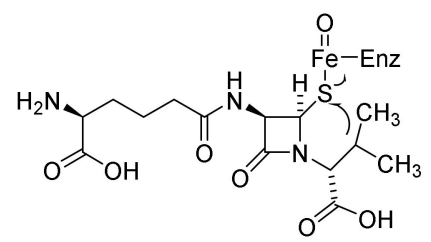

Scheme 5. Biosynthesis of the non-ribosomal peptide penicillin G [37]. EnzFe: isopenicillin $N$ synthase-FeII, transferase: isopenicillin $\mathrm{N} N$-acyltransferase [54]. 
A major step in developing later generations of penicillins was discovery of 6-aminopenicillanic acid in a broth used for production of the penicillins 22-26 (Figure 6, 38). Despite the level of molecules possessing the $\beta$-lactam ring the broth revealed an unexpected low antibiotic effect. This discrepancy was solved by the poor antibiotic effect of isolated 38 [55]. Access to the free amine facilitated syntheses of several penicillin analogues enabling development of later generations of penicillins $[38,42,56,57]$.<smiles>CC1(C)S[C@@H]2NC(=O)N2C1C(=O)O</smiles>

Figure 6. 6-Aminopenicillanic acid (38).

\subsection{Mechanism of Action of Penicillins}

The cell wall or cell envelope is and essential polymer surrounding and enclosing bacteria, Defects in the polymer might be lethal [52]. Several enzymes and transporters are involved in the construction of the cell wall including several penicillin-binding peptides (PBP). The cell wall of Staphylococcus aureus is fortified by crosslinking strands of peptidoglycans with strands of peptides as illustrated by the cartoon shown in Figure 7 [52,58]. The L-lysine residue is replaced with meso-diaminopimelic acid in other bacteria [44].

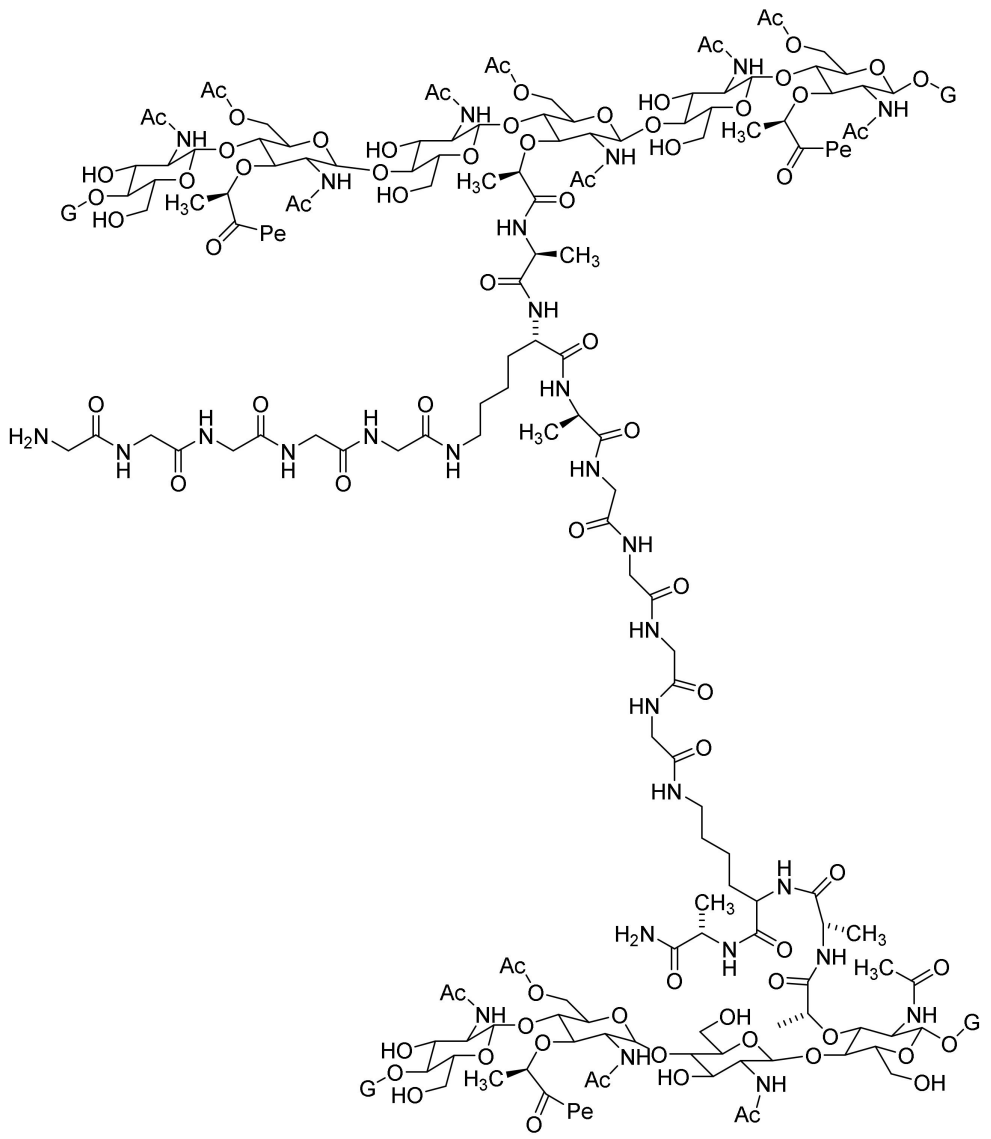

Figure 7. Cartoon illustrating the cross binding of peptidoglycan strands in the cell walls of Staphyllococcus aureus $[52,58]$. Pe indicates the attachment of an additional cross binding peptide by a peptide bond to $\mathrm{N}$-acetymuramic acid. $\mathrm{G}$ indicates prolongation with other units of the dimer $\mathrm{N}$-acetylglucosamine- $\mathrm{N}$-acetylmuramic acid. 
The cross binding occurs by elimination of the terminal D-alanine in one peptidoglycan strand by an attack of the amino bond of a glycine residue terminating a side chain in another peptidoglycan strand (Figure 8) [52]. Hereby a cross linking of the two peptidoglycan strands is obtained. This mechanism deviates from pervious described mechanism for cross binding [44].

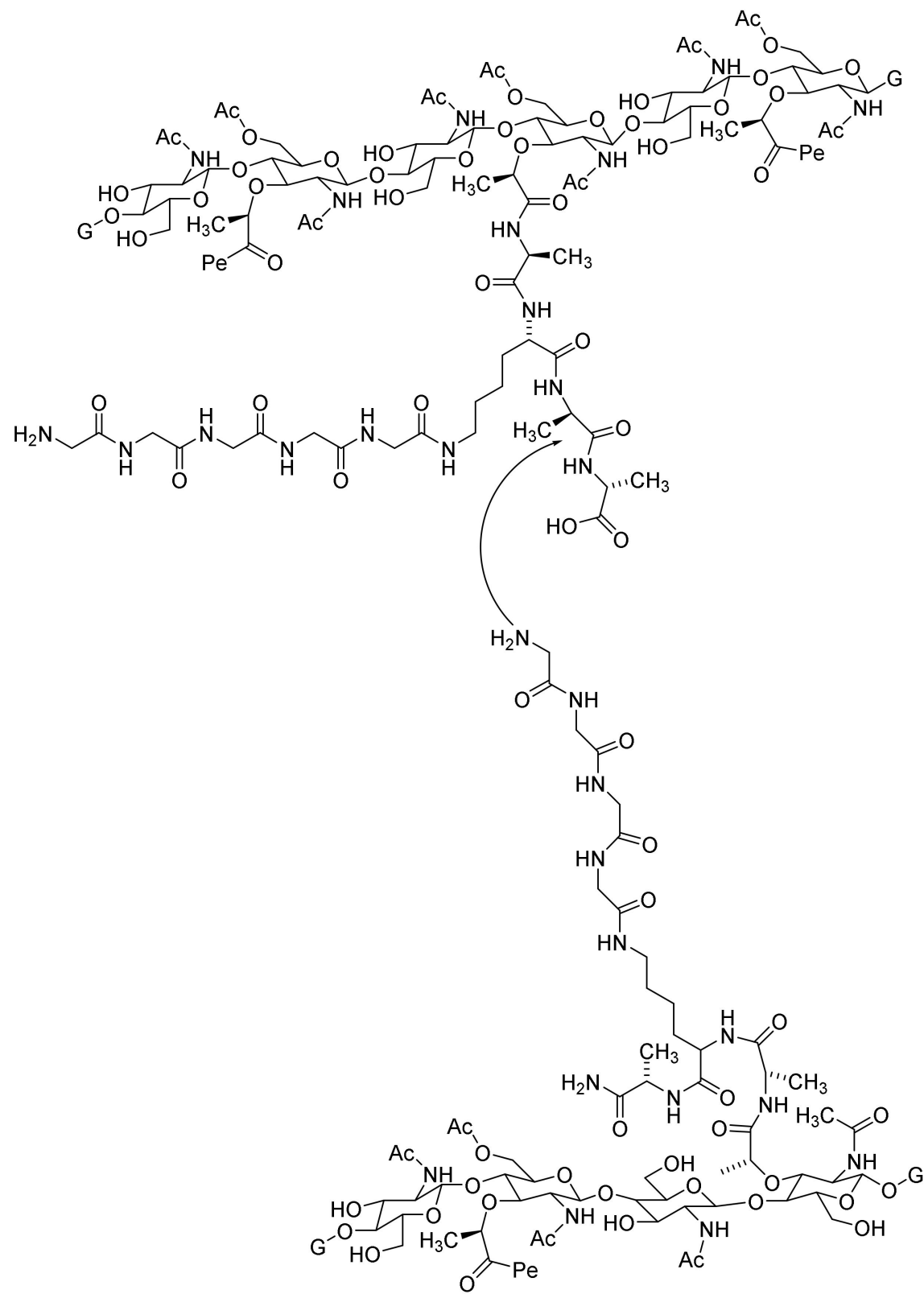

Figure 8. Mechanism for cross binding [44,58]. Pe indicates the attachment of an additional cross binding peptide by a peptide bond to $\mathrm{N}$-acetymuramic acid. $\mathrm{G}$ indicates prolongation with other units of the dimer $N$-acetylglucosamine- $N$-acetylmuramic acid.

The penicillin nucleus is isoster to the terminal D-Ala-D-Ala unit essential in the cross binding process (the Tipper-Strominger hypothesis) [59]. By interacting with and acylating the serine hydroxyl group in the penicillin-binding transpeptidases [60] cross binding and consequently formation of a stable cell wall in the bacteria is prevented $[44,52]$. It was hypothesized that the $6 \alpha$-methyl analog of penicillin was a closer analog to the D-Ala-D-Ala target. Surprisingly, the compound showed much poorer activity [61].

Gram-positive and Gram-negative bacteria differ in Gram-staining. Gram-negative bacteria possess an outer cell membrane, which prevents some antibiotics from reaching 
their target molecules. The outer membrane possess protein channels (porins) allowing small molecules such as nutrients or antibiotics to penetrate down a concentration gradient to reach the inner parts of the bacteria [38].

\subsection{Late Generations Penicillins}

The first isolated penicillins were characterized by simple acyl groups at N-6 (Figure 5). All of these have the drawback that they to a large extent are degraded in the acidic medium in the stomach. In addition they only show activity against a narrow spectrum of bacteria. Access to 6-aminopenicillanic acid (38) facilitated synthesis of analogues with different acyl groups. Today 38 is prepared by enzymatic cleavage of penicillin $G(24)[44,55]$. Compound 38 had previous been mentioned but the potential was never realized by the Japanese scientists [62]. Early successes with semisynthetic penicillins were obtained by preparing amides of phenoxyacetic acids (39-41) [55]. The compounds are also named phenoxyalkyl penicillins. The compounds $\mathbf{4 0}$ and $\mathbf{4 1}$ are administered as racemic mixtures. The phenoxyacetamides are more acid resistant and are adsorbed about four times more efficient from the stomach $[63,64]$. The presence of an oxygen atom $\beta$ to the carbonyl group makes the side chain carbonyl much less electrophilic and prevented reaction with the lactam carbonyl in acidic media $[38,42]$. The compounds were developed in the late 1950s [42,55]. Phenoxymethyl penicillin (39-41) and penicillin G (24) are used orally for treatment of strains of Gram-positive cocci [65]. The compounds with simple carboxylic acids in the side chain are classified as first generation penicillins $[37,66]$

The second generation penicillins consists of aminopenicillins such as 42-45 (Figure 9). Introduction of the amino group, which will be protonated in acidic media, makes the compounds less acid labile [38]. These penicilllins are active against Gram-positive as well as Gram-negative bacteria such as Haemolhillus influenza, E. coli and Proteus mirabilis. They have good bioavailability after oral administration [20,43,44]. Ampicillin was the first penicillin with some activity against Gram-negative bacteria [55]. The introduction of a hydroxyl group in the para position of the phenylglycine residue of ampenicillin to give amoxicillin (44) improved the absorption after oral administration. Amoxicillin was marketed in 1964 [38] and became one of the most widely prescribed penicillins [67]. The aminopencillins were developed in the early 1960s [55].<smiles>[R]N[C@@H]1C(=O)N2[C@@H](C(=O)O)C(C)(C)S[C@H]12</smiles>

$38 \mathrm{R}=-\mathrm{H}$

$39 \mathrm{R}=$<smiles>CC(=O)COc1ccccc1</smiles>

$40 \mathrm{R}=$<smiles>CC(=O)C(C)Oc1ccccc1</smiles>

$41 \mathrm{R}=$<smiles>CCC(Oc1ccccc1)C(C)=O</smiles>

$42 \mathrm{R}=$<smiles>CC(=O)C(N)c1ccccc1</smiles>

$43 \mathrm{R}=$<smiles>CC(=O)C(N)C1=CCC=CC1</smiles>

$44 \mathrm{R}=$<smiles>CC(=O)[C@H](N)c1ccc(O)cc1</smiles>

$45 R=$<smiles>CC(=O)C1(N)CCCCC1</smiles>

Figure 9. Semisynthetic penicillins. Phenoxyacyl penicillins: phenoxymethyl penicillin/penicillin $\mathrm{V}$ (Vepicombin, 39), phenoxyethyl penicillin (phenithicillin, 40), Phenoxypropylpenicillin $(41)[63,64]$. Aminoacylpenicillins ampicillin (42), epicillin (43), amoxicillin (44) and cyclacillin (45). 
Introduction of an acidic group into the side chain made the penicillins 46-48 (Figure 10) clinically active against Pseudomonas aeroginosa and some Klebsiella infections [67] (third generation penicillins). Piperacillin (49) and mezlocillin (50) with bulky side chains are less sensitive toward $\beta$-lactamases and generate fourth generation penicillins [66] (Section 4.6). These penicillins also were efficient in treatment of $P$. aeruginosa infections in immunocompromised patients [67]. The drug is discontinued in the USA [43]. The ureido group in the side chain of piperacillin enhances cell wall penetration of Gram.negative bacteria affording activity also against species belonging to Pesudomonas, Klebsiella, Enterobacter and Citrobacter [20]. The drugs were developed in the late 1960s and the early 1970s [55].

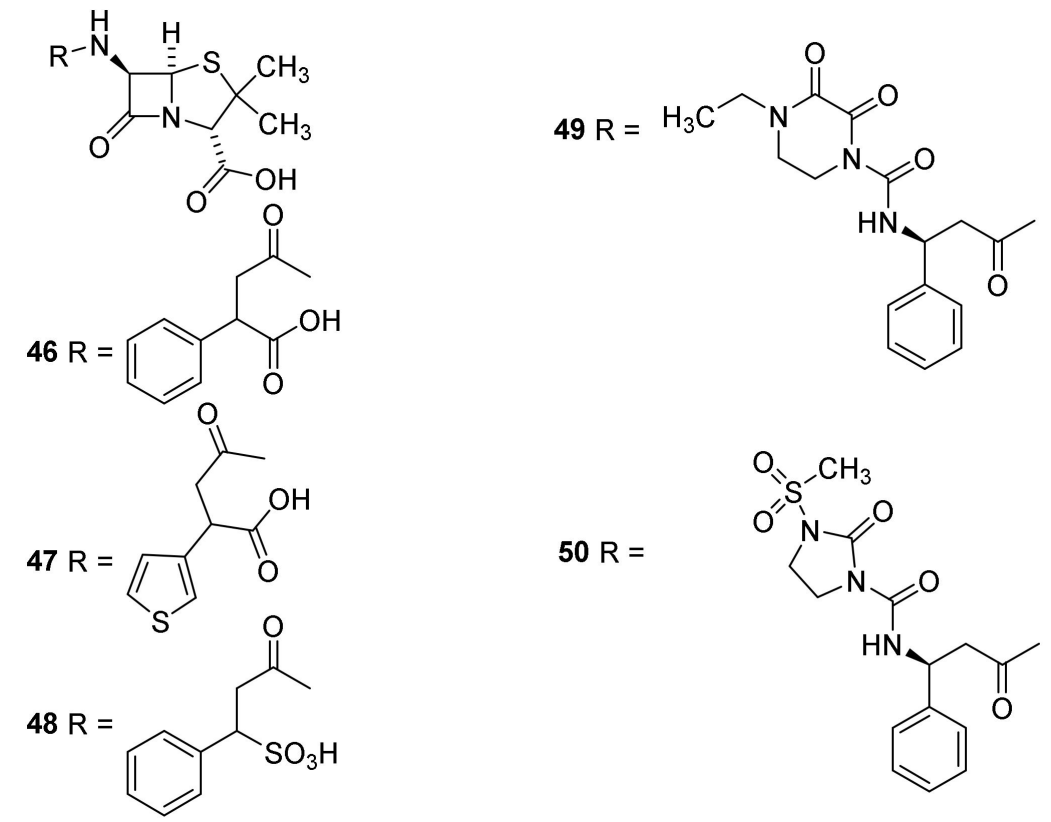

Figure 10. Semisynthetic penicillins with activity toward Pseudomonas aeruginosa Carbenicillin (46), sulbenicillin (47), ticarcillin (48) [44], piperacillin (49) and mezlocillin (50).

\subsection{Penicillin Hypersensitivity}

Due to reaction with the $\varepsilon$-amino group of lysine residues in proteins or disulfide formation between cysteine residues and degradation products of pencillins some patients may develop hypersensitivity following administration of penicillins. Fortunately most allergic reactions are benign [38]. Polymerization of ampicillin molecules caused by reaction of the amino group and the $\beta$-lactam may also result in allergens [38].

\subsection{Penicillin Resistance}

Microorganisms may become resistant to antibiotics targeting intracellular pathways by developing mechanisms pumping drugs out of the cells [26]. This strategy is useless for Gram-positive bacteria for disarming penicillins, since their target is the crosslinking of the cell envelope outside the cell membrane [52]. However, some Gram-negative bacteria such as Pseudomonas aeruginosa, E. coli and Neisseria gonorrhoeae possess an outer membrane with multidrug effective efflux pumps [68]. This outer membrane also might prevent small molecule-like antibiotics to penetrate to the penicillin-binding proteins [43].

Already Fleming discovered that the growth of Balantidium coli and several other bacteria was resistant to penicillin G [40]. This observation was made before penicillin $G$ (24) was taken to the clinic $[69,70]$. The resistant factor was transferred between different bacteria and was assumed to be an enzyme [71]. This assumption was confirmed by the discovery of the $\beta$-lactamases. These enzymes efficiently neutralize penicillins by opening the $\beta$-lactam ring to give penicilloic acid (33). Cleavage of the $\beta$-lactam ring removes the antibacterial effect $[43,52,72]$. In principle, this is the same acylation of a serine 
residue that occurs, when penicillins inactivates penicillin-binding proteins. However, the $\beta$-lactamases are not essential for the microorganism. Fast hydrolysis reactivates the enzyme enabling ring opening of other $\beta$-lactam rings [52]. Genes conferring resistance to antibiotics have been found in 30,000-year old organisms suggesting that resistance against antibiotics was invented by Nature millennia before mankind developed drugs against infectious diseases [70,73]. $\beta$-Lactamases are widely distributed $[70,71,74,75]$ and have been studied intensive because of their ability to neutralize the clinical effect of penicillins. In several pathogenic organisms, expression of $\beta$-lactamases is provoked by $\beta$-lactam antibiotics [76]. The $\beta$-lactamases are divided into three classes A (penicillin-hydrolyzing), $\mathrm{C}$ (cephalosporin-hydrolyzing) and D (oxacillin-hydrolyzing) and Class B the metallo- $\beta$ lactamases [44,70,72,77]. Class $C$ are primarily found in Gram-negative bacteria [44]. The cleaving catalyzed by serine- $\beta$-lactamases (Class A, C and D) involves a serine residue in the $\beta$-lactamases which react with the $\beta$-lactam to give an ester of the serine (Scheme 4). The enzyme penicillin complex is hydrolyzed to penicilloic acid (33) and reactivated $\beta$ lactamase $[44,72,77]$. In the metallo- $\beta$-lactamases a hydroxide complexed with two zinc ions in the active site opens the $\beta$-lactam [72]. A detailed mechanism of action of the different $\beta$-lactamases is given in some reviews [58,72].

Two approaches were initiated to overcome resistance against penicillins (1) syntheses of penicillins that are resistant to $\beta$-lactamases (fourth generation penicillins) and (2) use of $\beta$-lactamase inhibitors (Section 8). Other factors affecting the effect of antibiotics are population of bacteria and biofilm formation. Bacteria in biofilms are protected by the presence of extracellular polysaccharides [78]. Old colonies of bacteria often have a slower rate of proliferation and consequently a less sensibility toward the antibiotics. In addition a higher population and diversity of bacteria increases the likeliness of $\beta$-lactamase producing species [43].

Methicillin (Figure 11, 51), introduced to the clinic in 1960, was the first penicillin with reduced $\beta$-lactamase sensitivity $[43,57,79]$. Nafcillin (52) and oxacillin (53) with a steric bulk preventing hydrolysis followed later [38,44]. Evidence for the importance of the bulky methoxy groups is revealed by the sensitivity of homologous penicillins toward $\beta$-lactamases. Introduction of a methylene group between the dimethoxyphenyl and the carbonyl group in methicillin (51) increases the sensitivity of the molecules toward $\beta$ lactamases [38]. Methicillin (51) is not absorbed when given orally and cannot penetrate the outer membrane of Gram-negative bacteria8]. It is supplemented with nafcillin (52) and oxacillin (53) [38]. A drawback of isoxazolyl penicillins such as 53 is a high protein binding lowering the serum concentration [55,57]. Oxacillin (53) and nafcillin (52) are not approved in Japan, although they are standard therapy for treatment of infections with susceptible S. aureus and S. epidermis in the major part of the world [43]. Cefazolin is used instead [80].<smiles>[R]NC1C(=O)N2C(C(=O)O)SC(C)(C)[C@H]12</smiles>

$51 \mathrm{R}=$<smiles>COc1cccc(OC)c1C(C)=O</smiles>

$52 \mathrm{R}=$<smiles>CCOc1ccc2ccccc2c1C(C)=O</smiles>

$53 \mathrm{R}=$<smiles>CC(=O)c1c(-c2ccccc2)noc1C</smiles>

Figure 11. Examples of $\beta$-lactamase resistant penicillins, methicillin (51), nafcillin (52) and oxacillin (53). 
Another mechanism used by bacteria for gaining resistance against penicillins takes advantage of mutating the penicillin-binding proteins into enzymes distinguishing the penicillins from the endogenic substrate the D-Ala-D-Ala residue $[43,52,55,81]$. An example of such an enzyme is PBP2a produced by S. aureus [43,55]. Expression of PBP2a is the major reason for resistance against $\beta$-lactams. A surprising observation is that despite expression of PBP2a a synergistic effect of clavanulate, a $\beta$-lactamase inhibitor (Section 8), and $\beta$-lactam antibiotics is observed for S. aureus [52].

Penicillins substituted at C-6 were obtained by hypochlorite oxidation of penicillin $\mathrm{G}$ to give a intermediate chlorine derivative, which in methanol is converted into the $\alpha$-methoxy derivative (Scheme 6, 54) [82].

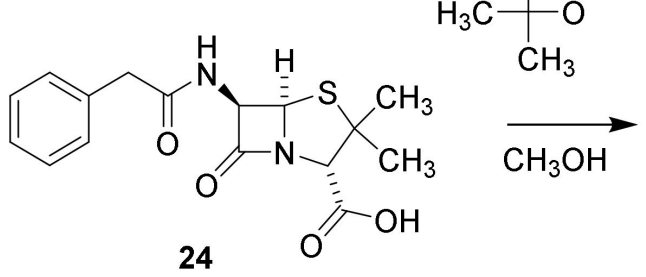<smiles></smiles>

Scheme 6. Conversion of penicillin G into the 6-methoxy derivative 54 [82].

Development of the technique for 6-methoxylation enabled preparation of temocillin, developed in 1980 (Figure 12, 55). Even though this compound has a long half live in the blood (about $5 \mathrm{~h}$ ) the antibacterial activity is restricted to multiple resistant Gramnegative bacteria [44]. Formidacillin (56) is highly potent against Gram-negative bacteria including Pseudomonas sp. and has some activity against Streptococcus sp. but none against Staphylococcus sp3]. The compound, however, never was approved as a drug by the FDA.<smiles>CC1(C)S[C@H]2[C@H](NC(=O)C(C(=O)O)c3ccsc3)C(=O)N2[C@@H]1C(=O)O</smiles>

55<smiles>CCN1CCN(C(=O)N[C@@H](C(=O)N[C@H]2C(=O)N3[C@@H](C(=O)O)C(C)(C)S[C@H]23)c2ccc(O)c(O)c2)C(=O)C1=O</smiles>

Figure 12. Temocillin (55) and formadicillin (56) [44]. Temocillin is approved by European Medicine Agency.

The ureidopenicillins azlocillin (Figure 13, 57), mezlocillin (58) and piperazillin (59) were developed in the 1970s. They are efficient for treatment of infections with Pseudomonas aeruginosa, Klebsiella and some Enterobacter species. Unfortunately, they have a poor effect on infections of Escherichia coli, Enterobacter and Salmonella species [38,83].

Since the 1970s, very few new antibacterial drugs possessing the penam carbon skeleton have been introduced. A search in To Market To Market from 2019 to 2006 (Annual Reports in Medicinal Chemistry and Medicinal Chemistry Reviews) revealed no penicillins brought to the market. In contrast, several drugs in which penicillins are combined with $\beta$-lactamase inhibitors has been approved [58,84]. 
<smiles>[R]N[C@@H]1C(=O)N2[C@@H](C(=O)O)C(C)(C)S[C@H]12</smiles>

$57 \mathrm{R}=$<smiles>CC(=O)[C@H](NC(=O)N1CCNC1=O)c1ccccc1</smiles>

$58 \mathrm{R}=$<smiles>CC(=O)[C@H](NC(=O)N1CCN(S(C)(=O)=O)C1=O)c1ccccc1</smiles>

$59 \mathrm{R}=$<smiles>CCC1CCN(C(=O)N[C@H](C(C)=O)c2ccccc2)C(=O)C1=O</smiles>

Figure 13. Ureidopenicillins: Azlocillin (51), mezlocillin (52) and piperazillin (53) [38].

\subsection{Penicillin Prodrugs}

Prodrugs, in which the carboxylic acid has been masked, were used for improving absorption of ampicillin (42). The first prodrug was pivampicillin (Figure 14, 60) marketed by Leo Pharma [57] in the 1970s [85]. Administration of pivampicillin afforded three time higher serum concentration of ampicillin and higher maximal serum concentration after one hour than after administration of an equimolar amount of ampicillin [86]. The pivalic acid released after cleavage of pivampicillin (58) to give ampicillin (42) might have an effect on the carnitine plasma level [87]. Additionally, talampicillin (61) [88], bacampicillin (62) [89] and lenampenicillin (63) [90] were absorbed efficiently.<smiles>[R]OC(=O)[C@H]1N2C(=O)[C@@H](NC(=O)[C@@H](N)c3ccccc3)[C@H]2SC1(C)C</smiles>

$60 \mathrm{R}=$<smiles>CC1OC(=O)c2ccccc21</smiles>

$62 \mathrm{R}=$<smiles>CCOC(=O)OC(C)C</smiles>

$61 \mathrm{R}=$<smiles>CCOC(=O)OC(C)(C)C</smiles>

$63 \mathrm{R}=$<smiles>CCc1oc(=O)oc1C</smiles>

Figure 14. Prodrugs of penicillin: talampicillin (60), bacampicillin (61), pivampicillin (62) and lenampenicillin (63) [42,44].

\section{Cephalosporins}

Discovery and Production of Cephalosporins

Cephalosporins contain the backbone cephem (Figure 4). Cephalosporin C was isolated from a wild strain of Cephalosporium in 1945 [91]. The molecular formula was published in 1955 [91,92] and the constitution 64 (Figure 15) in 1961 [93]. An X-ray analysis confirmed the constitution 64 [94]. Today Acremomium chrysogenum (formerly Cephalosporium acremomium) is primarily used for production of cephalosporins. Similar stereochemistry at the $\beta$-lactam ring in the penicillins and cephalosporins was established by a rearrangement of phenoxymethyl penicillin sulfoxide to a cephalosporin without changing the stereochemistry in the $\beta$-lactam ring (Scheme 7) [95]. 
<smiles>CC(=O)OCC1=C(C(=O)O)N2C(=O)C(NC(=O)CCCC(N)C(=O)O)[C@H]2SC1</smiles>

Figure 15. Cephalosporin C (64).<smiles>CC1(C)S[C@@H]2C(NC(=O)COc3ccccc3)C(=O)N2[C@H]1C(=O)O</smiles>

1) $\mathrm{HIO}_{4}$

2) $\mathrm{CH}_{2} \mathrm{~N}_{2}$<smiles>COC(=O)[C@H]1N2C(=O)[C@@H](NC(=O)COc3ccccc3)C[C@H]2S(=O)C1(C)C</smiles><smiles>Cc1ccc(S(=O)(=O)O)cc1</smiles><smiles>COC(=O)C1=C(C)CS[C@@H]2[C@H](NC(=O)COc3ccccc3)C(=O)N12</smiles>

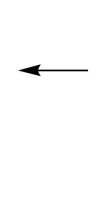

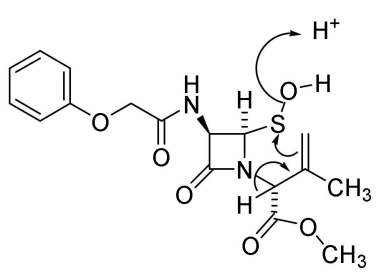

Scheme 7. Pencillin cephalosporin rearrangement [95].

The naturally occurring cephalosporin 64 is converted to the free amine by reaction of the protected acid with phosphorous pentachloride followed by hydrolysis of the intermediate iminoether (Scheme 8) [44,96,97]. Procedures for enzymatic cleavage of the amide avoiding hazardous reagents have also been developed [97].<smiles>CC(=O)OCC1=C(C(=O)O[Si])N2C(=O)C(NC(=O)CCCC(N)C(=O)O[Si](C)(C)C)[C@H]2SC1</smiles><smiles>CC(=O)OCC1=C(C(=O)O)N2C(=O)C(N)[C@H]2SC1</smiles><smiles>CC(=O)OCC1=C(C(=O)O[Na])N2C(=O)C(N=C(Cl)CCCC(N)C(=O)O[Si](C)(F)Cl)[C@H]2SC1</smiles>

$\mathrm{HOCH}_{2} \mathrm{CH}_{2} \mathrm{CH}_{3}$<smiles>CCCOC(CCCC(N)C(=O)O[Si](C)(F)F)=NC1C(=O)N2C(C(=O)OC(C)(C)C)=C(COC(C)=O)CS[C@H]12</smiles>

Scheme 8. Cleavage of the 7-amide group of cephalosporins [44,97].

From a biosynthetic point of view, cephalosporin-like penicillin is a non-ribosomal tripeptide originating from peptide $\zeta$-D-aminoadipidoyl-L-cysteinoyl-D-isovalerine. However, after formation of the penicillin (Scheme 5) the 2 position in D-2-aminoadipic residue is isomerized, a radical formation at one of the methyl groups in valine and a ring expansion occurs to give the cephalosporin nucleus. After oxidation and acetylation of the methyl group cephalosporin C (61) is formed (Scheme 9) [37,54]. The penicillin-cephalosporin rear- 
rangement described in Scheme 7 shows resemblance to the biosynthesis of cephalosporin from penicillin $\mathrm{N}$.<smiles>CC1(C)S[C@@H]2C(NC(=O)CCC[C@H](N)C(=O)O)C(=O)N2C1C(=O)O</smiles>

Isomerase

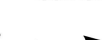<smiles>CC1=C(C(=O)O)N2C(=O)[C@@H](NC(=O)CCC[C@H](N)C(=O)O)[C@H]2SC1</smiles>

Acetylaion<smiles>CC(=O)OCC1=C(C(=O)O)N2C(=O)[C@@H](NC(=O)CCC[C@H](N)C(=O)O)[C@H]2SC1</smiles>

64<smiles>CC1(C)S[C@@H]2C(NC(=O)CCC[C@H](N)C(=O)O)C(=O)N2C1C(=O)O</smiles>

Radical formation

$\downarrow$<smiles>CC1(C)S[C@H]2[C@H](NC(=O)CCC[C@H](N)C(=O)O)C(=O)N2[C@H]1C(=O)O</smiles>

Scheme 9. Biosynthesis of cephalosporin C (64). Isomerase: isopenicillin $\mathrm{N}$ isomerase, ring expansion, oxidation and acetylation: deacetylcephalosporin C/deacetylcephalosporin C synthase-FeII, acetylation deacetylcephalosprin C acetyltransferase [37,54].

Like the pencillins the cephalosporins are classified in generations [66]. The first generation of cephalosporins (narrow spectrum) consists drugs such as cephalexin (Figure 16, 65), cefadrine (66) and cefadroxil (67). First generation drugs have activity against Grampositive bacteria such as Staphylococcus aurea, Streptococcus species, even though they are expressing $\beta$-lactamases, and a few Gram-negative bacteria e.g., E. coli, H. influenza and Klebsiella species. They are used against uncomplicated skin and soft tissue infections [37,98,99]. Drugs belonging to second generation (intermediate spectrum activity) are cefalclor (68) and cefuroxime (69). They possess some activity against aerobic Gram-negative bacteria such as species of Moraxella, Neisseria, Salmonella, and Shigella [98,99]. They are used against upper and lower respiratory tract infections, sinusitis, and otitis media [99].
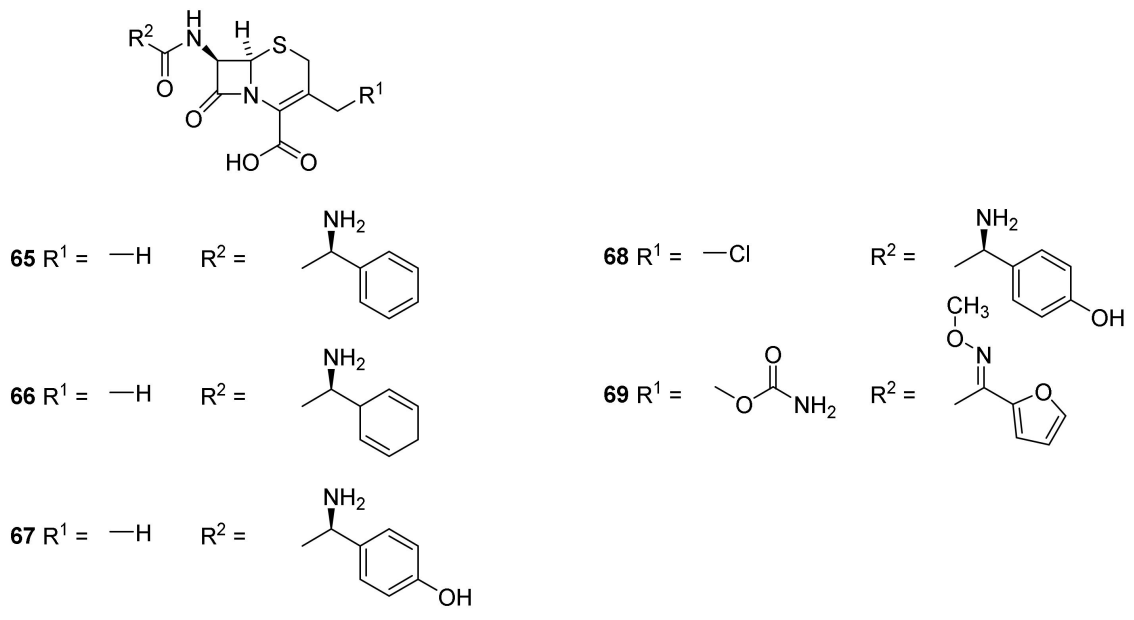

Figure 16. Examples of first generation cephalosporins. Cephalexin (65), cefadrine (66) and cefadroxil (67). Second generation cephalosporins cefalclor (68) and cefuroxime (69). 
Examples of third generation (broad spectrum activity) cephalosporins are cefotaxime (Figure 17, 70), ceftazidime (71), ceftriaxone (72), and ceftizoxime (73) $[38,98,99]$. The introduction of a methoxime group (74-76) makes the compound substrate for a tripeptide transporter in the intestinal mucosoal membrane [38]. They have good activity against most Gram-negative bacteria and are less sensitive toward $\beta$-lactamase [99]. In addition, they possess some activity toward Gram-positive bacteria and some methicillin resistant strains [99]. Cefepime (74), cefpirome (75), and cefquinome (76) belong to the fourth generation of cephalosporins (broad spectrum activity). By introduction of an ammonium ion the ability to penetrate the outer membrane in Gram-negative bacteria is increased [38]. They are effective against several resistant bacteria such as Gram-positive cocci, Streptococcus pneumoniae, Entero-bacteriaceae, and Pseudomonas aeruginosa strains. They are used for treatment of meningitis $[98,99]$. Fifth generation cephalosporins (extended spectrum activity) encompasses ceftobiprole (77) and ceftraoline (78). Ceftobiprole (77) is a very broad spectrum cephalosporin with activity against Gram-positive cocci, including MRSA and methicillin resistant Staphylococcus epidermidis (MRSE), penicillin-resistant Streptococcus pneumoniae, Enterococcus faecalis and many Gram-negative bacilli including $\beta$-lactamases groups $C$ producing E. coli and Pseudomonas aeruginosa [99]. Cefepime (74) has a $\gamma$-aminobutyric acid residue in the structure meaning that after penetrating the bloodbrain-barrier it might have neurotoxic effects [38]. Ceftaroline fosamil (78) is an example of a fifth generation cephalosporin. It is used against multidrug-resistant Staphylococcus aureus, including MRSA, VRSA, and VISA [99]. Ceftaroline fosamil is a water soluble prodrug which in the organism is dephosphorylated to yield ceftaroline [100]. Ceftaroline fosamil was approved by the FDA (2010) and the European Medical Agency (2012).<smiles>[R]C(=O)N[C@H]1C(=O)N2C(C(=O)O)=C([R])CS[C@H]12</smiles>

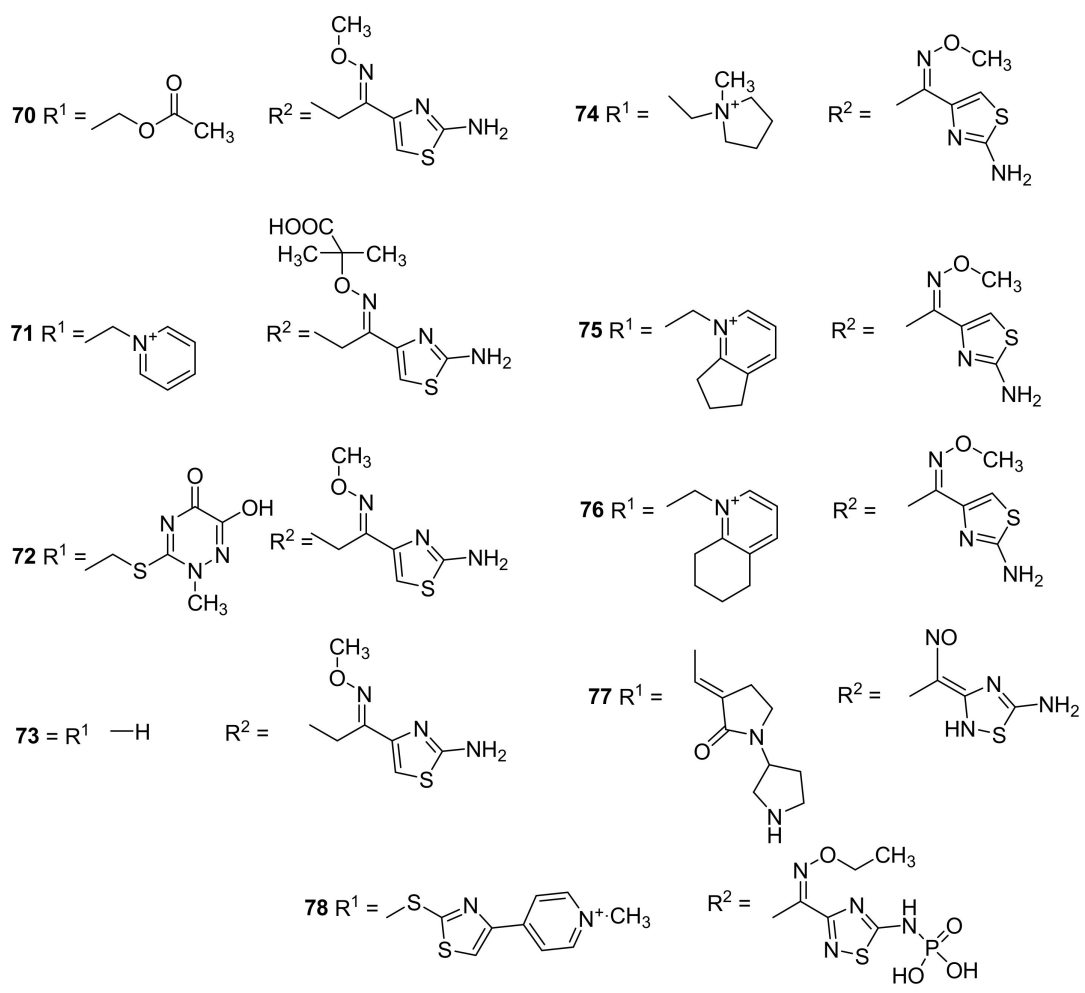

Figure 17. Third generation cephalosporins. Cefotaxime (70), ceftazidime (71), ceftriaxone (72) and ceftizoxime (73). Fourth generation cephalosporins. Cefepime (74), cefpirome (75) and cefquinome (76). Fifth generation cephalosporins: ceftobiprole (77) and ceftaroline fosamil (78) [98,99]. 
Cephalosporin hypersensitivity is unusual. The seldom cases are in general benign. Cross reaction between penicillin allergy and cephalosporin allergy has not been observed [38].

\section{Carbapenems}

Carbapenems (Figure 4) are characterized by a backbone consisting of the same bicyclic ring system as penicillin, but possessing a double bond between C-2 and C-3 and a carbon atom in the 1 position. The two hydrogen atoms at C-5 and C- 6 are trans disposed in clinical important carbapenems in contrast to the cis disposed C -5 and C-6 hydrogens in penicillins and the C-6 and C-7 cis disposed hydrogens in cephalosporins [101]. This might explain a lower sensitivity toward some $\beta$-lactamases $[38,101]$. The first isolated carbapenem was olivanic acid isolated from the broth of Streptomyces clavuligerus (Figure 18, 79). Due to penetration problems this compound was not pursued [101]. The $R$-1-hydroxyethyl group at C-6 appears to be optimal for an antibiotic effect of carbapenems. As described in Sections 3 and 4 the sidechain at C-6 in peniclllins and C-7 in cephalosporins might be substituted to improve the clinical effect [101]. Thienamycin (80) was isolated from the broth of Streptomyces cattleya [101]. The presence of an electrophilic $\beta$-lactam ring and a nucleophilic amino group makes thienamycin unsuitable as a drug because of intermolecular amid formation [38].
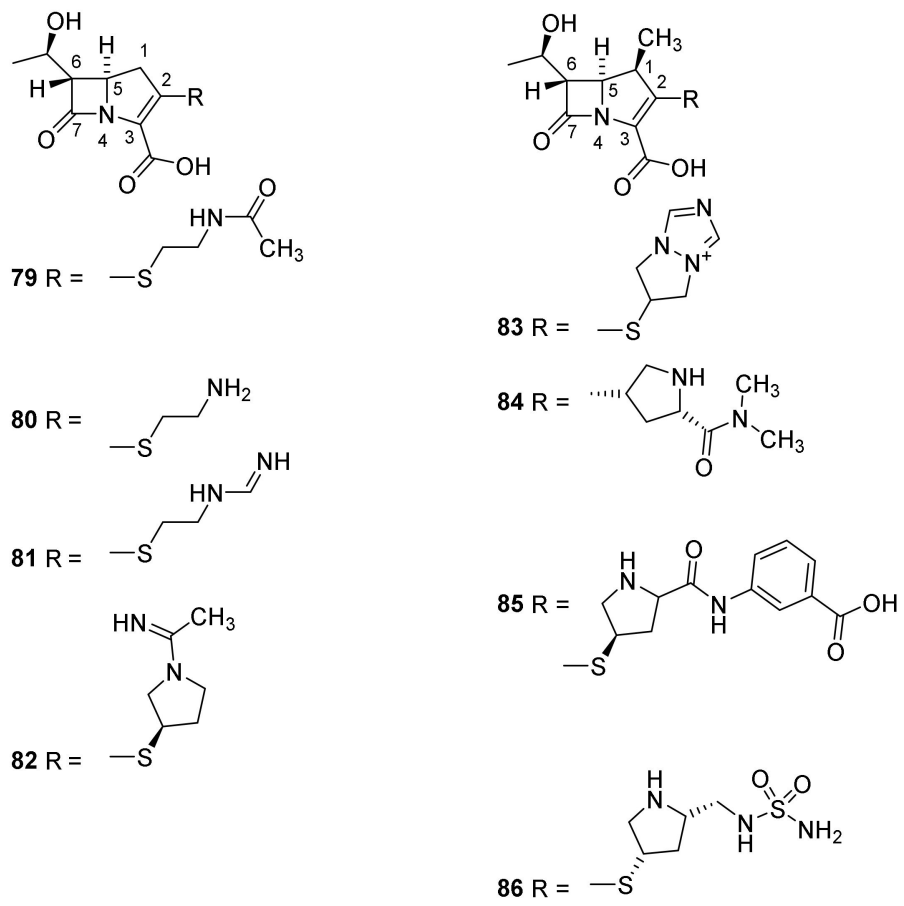

Figure 18. Carbapenems and 1-methylcarbapenems. Olivanic acid (79), thienamycin (80), imipenem (81), panipenem (82), biapenem (83), meropenem (84), ertapenem (85) and doripenem (86) [101].

In general, the in vitro spectrum of activity of the carbapenems is broader than that of penicillins and cephalosporins. Imipenem (81), penipenem (82) and doripenem (86) are used against infections with Gram-positive bacteria. The introduction of the amidine group in imipenem (81) ensures protonation at physiologic $\mathrm{pH}$ preventing a cleavage of the $\beta$-lactam ring [38]. Imipenem was approved as a drug in 1985 [38]. Biapenem (83), meropenem (84), ertapenem (85) and doripenem (86) to some extend show activity against Gram-negative bacteria. Meropenem was approved in 1996 [38]. In combination, meropenem (84) and the $\beta$-lactamase inhibitor clavulanic acid (Section 3.1) have an effect on methicillin drug resistant Mycobacterium tuberculosuis, a bacterium otherwise resistant toward $\beta$-lactam antibiotics [101]. The presence of a $\beta$-methyl group at $C-1$ prevents the 
carbapenems from being hydrolyzed in the kidney by renal dihydropeptidase-1 [102] and consequently prolong the effect by reuptake [38,103]. Doripenem (86) and ertapenem (85) were approved in 2007 and 2001, respectively [38].

In contrast to other $\beta$-lactam antibiotics, large scale production of carbapenems is based on synthesis and not fermentation [104]. Pioneering efforts making the compounds available for clinical use were performed by the Merck group [105-107] supported by others [108]. Review of methods for constructing the azetidinone intermediates have been published [109].

Different strategies for developing resistance are (1) reducing the sensitivity of penicillinbinding enzymes for carbapenems by mutation, (2) altering porins, expression of efflux pumps or (3) expression of $\beta$-lactamases. In Gram-positive cocci resistance is typically caused by mutation of penicillin-binding proteins. In Gram-negative rods expression of $\beta$-lactamases, porin change or/and alterations of penicillin-binding proteins makes the bacteria more resistant [101].

In the clinic treatment of patients with community-acquired pneumonia with meropenem (84), ertapenem (85) or imipenem (81) combined with cilastatin, a dihydropeptidase1 inhibitor has shown overall god response [103]. Patients suffering from nosocomial pneumonia responded more positive after treatment with meropenem (84) than after treatment with ceftazidime (71) combined with tobramycin [103]. Carbapenems also have shown good effects on hospital-acquired pneumonia and cystic fibrosis [103]. Complicated intra-abdominal infections have been treated successfully with imipenem (81), meropenem (84), ertapenem (85) and doripenem (86) [103]. Meropenem (84) and doripenem (86) as single therapy and iminipem (81) combined with cilastatin have been shown to have good effects on urinary tract infections [103]. Ertapenem (85), and meropenem (84) in combination with cilastatin have shown positive response in treatment of complicated skin and soft tissue infections [103]. The carbapenems are classified into three groups: Group 1 such as ertapenem (85) broad spectrum carbapenems with limited activity against non-fermentative Gram-negative bacilli but suitable for treatment of community-acquired infections. Group 2: imipenem (81), meropenem (84) and doripenem (86) are broad spectrum carbapenems, with activity against non-fermentative Gram-negative bacilli. They have less sensitivity to base promoted hydrolysis in solution. Group 3 carbapenems are clinical activity against resistant $S$. aureus. The latter group is still under development [110].

A drawback of the carbapenems is poor oral activity [110]. To overcome this problem a prodrug, tebipenem pivoxil (Figure 19,88) was prepared. The prodrug strategy is analogous to the principle used for pivampicillin (59) the prodrug of ampicillin (42). At the present this compound is under development as an orally active drug against pathogens causing respiratory tract infections [111]. Sanfetrinem (89) is the first tricyclic carbapenem. It possesses several interesting in vitro activities [110].
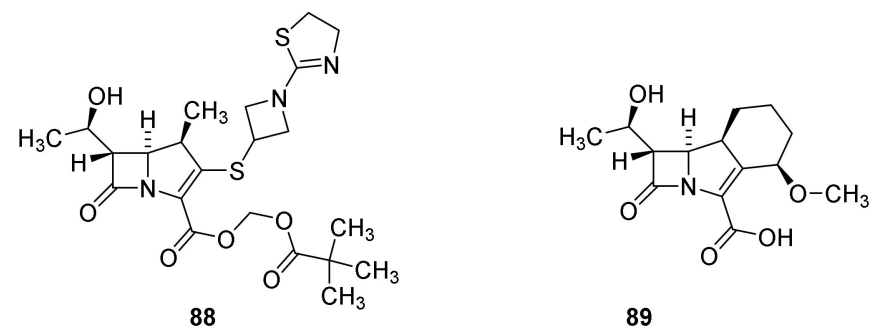

89

Figure 19. Tebipenem pivoxil (88) and sanfetrinem (89).

\section{Thiopenems}

The synthesis of faropenem (Figure 20,90) was published in a patents and Chinese journals between 2000 and 2010 [112]. The prodrug faropenem medoximil (91) is well absorbed after oral administration [38]. A synthesis of sulopenem (92) is published [113]. The key reaction is a triethoxyphosphine catalyzed thiopenem cyclization of the intermediate $\mathbf{9 4}$ (Scheme 10). Sulopenem is also administered as a prodrug sulopenem etzadrozil (93) [38]. 
Introduction of a C-C double bond in the thiazolidine ring and the presence of a sulfur atom reduce ring tensions and reduce the reactivity of the $\beta$-lactam ring. The thiopenems are active against Gram-positive cocci, Streptococcus pneumoniae and Gram-negative bacteria but not against Pseudomonas aeruginosa $[38,114]$. No thiopenem are found on the homepage of the European Medical Agency (August 2021) indicating that no thiopenem is approved as a drug. The FDA previously have rejected the registration of faropenem [115].<smiles>CC(O)[C@H]1SC(C2CCCO2)=C(C(=O)O)N1C(=O)O</smiles>

$90 \mathrm{R}=-\mathrm{H}$

$91 \mathrm{R}=$<smiles>CCc1oc(=O)oc1C</smiles>

$92 \mathrm{R}=-\mathrm{H}$

$93 \mathrm{R}=$<smiles>[R]OC(=O)C1=C(SC2CCS(=O)C2)S[C@@H]2[C@@H](C(C)O)C(=O)N12</smiles><smiles>[R]#CCOC(=O)C(CC)CC</smiles>

Figure 20. Faropenem (90), faropenem medoximil (91), sulopenem (92) and sulopenem etzadrozil (93).<smiles>C=C(Cl)COC(=O)C(=O)N(CC(=S)SC1CCS(=O)C1)C(=O)C(C(C)O)C(C)O</smiles>

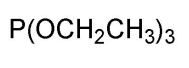<smiles>C=C(Cl)COC(=O)C1=C(SC2CCS(=O)C2)SC2C(C(C)OCC)C(=O)N12</smiles>

Scheme 10. Formation of the thipenem skeleton [113].

\section{Monobactams}

The monobactam goup is the last discovered types of $\beta$-lactams. The first description is in a Japanese patent from 1979. For structure elucidation sulfazecin (Scheme 11, 95) isolated from the broth of Pseudomonas species was converted to D- $\gamma$-glytamyl-D-alanylamide and 2-oxo-3-sulfaminopropionic acid by hydrolysis with M hydrochloric acid [116,117]. The compound showed varying MIC from $0.4 \mu \mathrm{g} / \mathrm{mL}$ for Escherichia coli to $800 \mu \mathrm{g} / \mathrm{mL}$ for Bacillus cereus. Several other monobactams were isolated from Chromobacterium violaceum and other bacteria [117].<smiles>COC1(NC(=O)C(C)NC(=O)CCC(N)C(=O)O)C(=O)N(S(=O)(=O)O)C1C</smiles><smiles>CC(NC(=O)CCC(N)C(=O)O)C(N)=O</smiles>

Scheme 11. Hydrolysis of sulfazecin (95).

Aztreonam (Figure 21, 96) is an example of a monbactam introduced on the market. The drug is derived from sulfazecin (95) by removal of the methoxy group and introduction of one of the side chain known from other $\beta$-lactam antibiotics [38]. It easily penetrates the outer membrane of Gram-negative aerobes such as Pseudomonas aeruginosa. Poor 
absorption from the gastro-intestinal duct makes intramuscular injection the preferred way of administration [38,118].<smiles>C[C@H]1C(NC(=O)C(=NOC(C)(C)C(=O)O)c2csc(N)n2)C(=O)N1S(=O)(=O)O</smiles>

96

Figure 21. Aztreonam (96).

Carbapenemases particularly efficient in cleaving carbapenems have been discovered [77].

\section{9. $\beta$-Lactamase Inhibitors}

By far the major reason for resistance of bacteria against $\beta$-lactam antibiotics is expression of $\beta$-lactamases $[72,77,119]$. An important strategy for combating pathogenic resistant bacteria therefor is to inactivate $\beta$-lactamases by co-administration of $\beta$-lactam antibiotic drugs and $\beta$-lactamase inhibitors. Carbapenems are less sensitive to $\beta$-lactamases due to the different stereochemistry on the lactam ring [101]. The use of combination therapy is complicated by different absorption, metabolism and kinetic of the antibiotic and the $\beta$-lactamases inhibitor. In principle, these parameters are unique for every patient. In most cases, however, the combination drugs are distributed in fixed ratios [120]. The inhibitors might be of the three well-known types the $\beta$-lactam type, the diazabicyclooctane type and the boronic acid type. Clinical results for the use of some approved $\beta$-lactam- $\beta$-lactamase inhibitor combinations have been reviewed $[119,120]$.

\subsection{The $\beta$-Lactam Type of $\beta$-Lactamase Inhibitors}

The first inhibitor to be discovered was clavulanic acid (Figure 22, 97). It was discovered in a Streptomyces broth because growth of a penicillin-resistant Klebsiella aerogenes in a medium containing penicillin G (24) was inhibited. Thus, the presence of clavulanic acid (97) in the broth made Klebsiella aerogenes sensitive toward penicillin. [38,121,122]. The nucleus is an oxapenam isosteric to the carbapenam. The absence of a C-6 side chain deprives the molecule from a significant antibiotic effect but gives the molecule high affinity for $\beta$-lactamases [38]. Clavulanic acid inhibits serine $\beta$-lactamases but not metallo$\beta$-lactamases [119]. Two combinations of amoxicillin (44) and clavulanic acid (97) in two different ratios (marketed as augmentin and timentin) are approved by the U.S. Food and Drug Administration (FDA) for treatment of infections with e.g., Streptococcus pneumoniae, Haemophilus influenza, Moraxella catarrhailis, Klebsiella spp., S. aureus and Escherichia coli [119]. Sulbactam (98) is a thiopenamdioxide with no C-6 side chain depriving an antibiotic effect [38]. It is approved to be used in combinations in different ratios with ampicillin (42) and cefoperazone for treatment of infections of S. aureus, E. coli, Klebsiella spp. and Enterobacter cloaceae [119]. In 1993 tazocin a combination of tazobactam (99) and piperacilllin (49) was introduced to treat infections with S. aureus, S. pneumoniae and E. coli [119]. Enmetazobactam (100) possesses a quaternary ammonium group, which together the carboxylate result in a net neutral compound with enhanced cell permeability. The enzyme group also increases affinity to spectrum $\beta$-lactamase of class A and D [119]. The $\beta$-lactamase synergistically augment the effects of penicillins sensitive to $\beta$-lactamases [58]. 

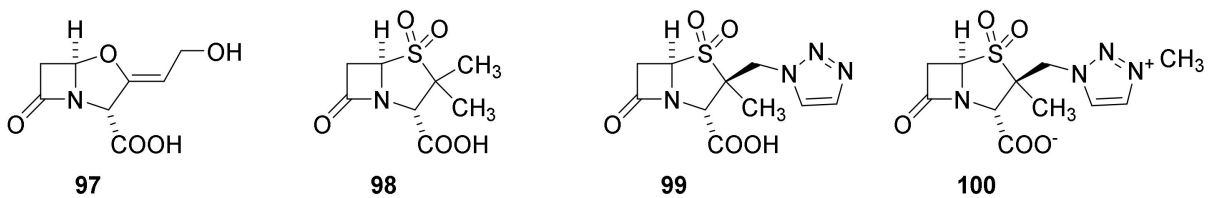

Figure 22. $\beta$-Lactamase inhibitors containing a $\beta$-lactam residue in the skeleton: clavulanic acid (97), sulbactam (98), tazobactam (99) and enmetazobactam (100) [119].

Sulbactam (98) is asumed to react irreversible with the $\beta$-lactamase as illustrated in Scheme 12 [123]:

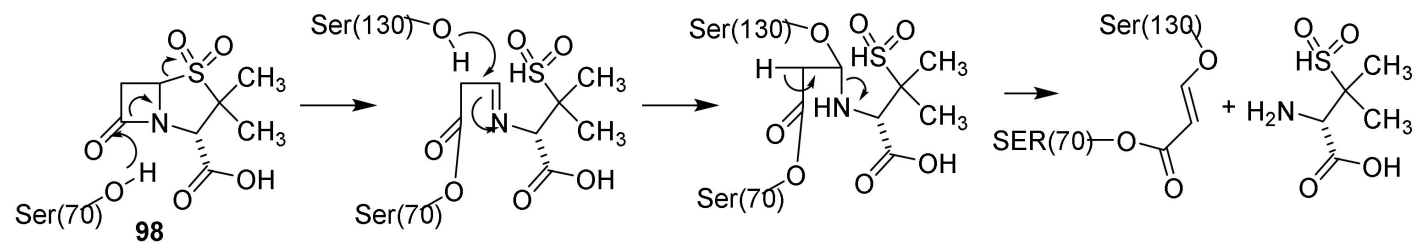

Scheme 12. Irreversibel reaction between sulbactam (98) and $\beta$-lactamase [123].

\subsection{The Diazabicyclooctane Type of $\beta$-Lactamase Inhbitors}

Design of the diazabicyclooctane group was inspired by the naturally occurring lactivicin (Scheme 13, 101) isolated from the broth of Empedobacter lactamgenus and Lysobacter albus $[124,125]$. The compound is a non-ribosomal dipeptide, in which the skeleton is derived from a serine and a glutamic acid. In solution an equilibrium between the two epimers at the quaternary carbon in the isoxazolidin-2-one ring is established [126]. Even though lactivicin is not a $\beta$-lactam but an isoxazilidin-2-one it stills react with penicillinbinding proteins and was found to be active against Streptococcus pneumoniae strains. The compound is highly active against Gram-positive bacteria and has modest activity against Gram-negative bacteria [125]. Other derivatives such as the phenoxy derivative 102 were found to be active against several clinically relevant Gram-negative strains such as Pseudomonas aeruginosa [58]. The discovery of lactivicins ability to acylate penicillinbinding peptides led to test of other heterocycles to find new heterocycles able to inactivate penicillin-binding peptides.

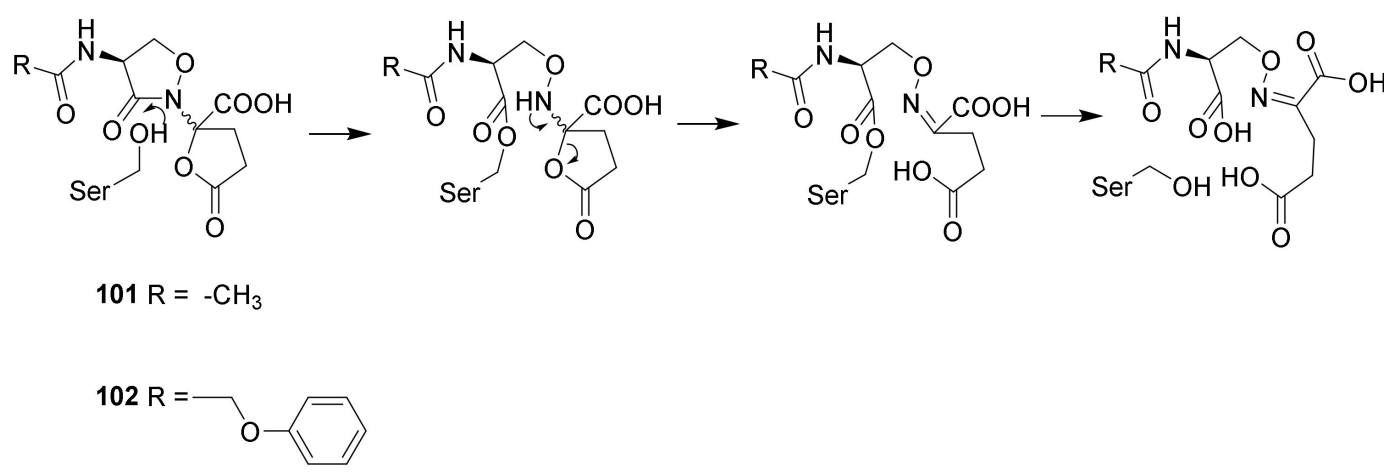

Scheme 13. Reaction of lactivicin (101) and phenoxylactivicin (102) with pencillin binding proteins [58].

Soon it was observed that the imidazolin-2-one residue in the diazabicyclo[3.2.1\}octane also reacts with $\beta$-lactamases. Consequently, synthesis and testing of similar compounds was initiated in several pharmaceutical companies. As result of these efforts avibactam (Figure 23, 103) was discovered [58]. Avibactam has antibacterial effect but is approved for clinical use in combination with ceftazidime (71) (Avycaz) [58,127]. A diazbicyclooctane such as $\mathbf{1 0 4}$ has antibacterial activity [58]. 


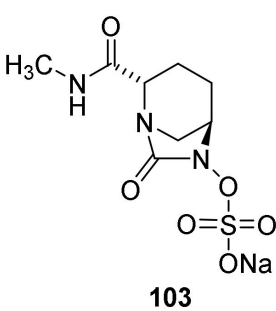

103

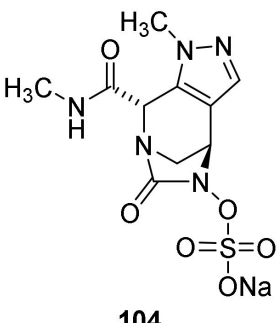

104

Figure 23. Avibactam (103) and NXL-105 (104).

The mechanism for the reaction of avibactam (103) with penicillin-binding peptides (PBP) is depicted in Scheme 14. Like in the $\beta$-lactams a reactive amide, in this case a carbamate, is the functional group. The presence of a sulfate ester makes the nitrogen a better leaving group. The hydrophilic carbamoyl group makes a more stable complex with the serine- $\beta$-lactamases than do other $\beta$-lactam lactamase inhibitors such as clavulanic acid [58]. The carbamoyl-lactamase complex is surprisingly stable [58].

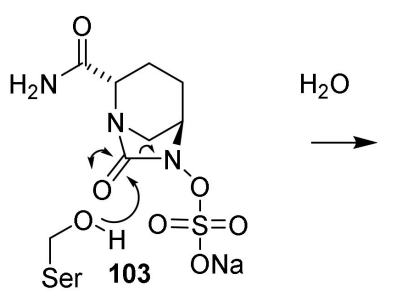<smiles>NC(=O)[C@@H]1CC[C@@H](NOS(=O)(=O)O)CN1C(=O)OC[Se]</smiles><smiles>O</smiles><smiles>NC(=O)[C@H]1CC[C@@H](O)[C@H](N(O)C[PH2+])N1C(=O)OC[SeH]</smiles>

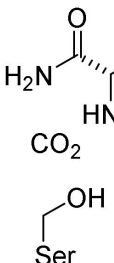<smiles>CC(C)(C)C1(C)CCCCC1</smiles><smiles>NC(=O)[C@H]1CCC(=O)CN1C(=O)OC[GeH3]</smiles><smiles>O</smiles><smiles>N=C1CC[C@@H](C(N)=O)N(C(=O)OCC2CCCCC2)C1</smiles>

Scheme 14. Reaction of avibactam (103) with PBP. The carbamoyl-lactamase complex is more stable than the analogous complexes between lactamase inhibitors of the $\beta$-lactam type [58].

Ceftazidime (71) and avibactam (103) as combination therapy has been introduced to meet the urgent need for antipseudomonal antibiotics [128].

\subsection{Boronic Acid $\beta$-Lactamase Inhibitors}

The first boronic acid $\beta$-lactamase inhibitor to be used in the clinic was vaborbactam (Figure 24, 105) in combination with meropenenem (84). The 1:1 combination is marketed as varbomere cures urinary tracts infections caused by Enterobacteriaceae resistant against the normally used drugs such as cephalosporins, fluoroquinolones and carbapenems [129]. Varbomere is also used against infections of the kidneys (pyelonephritis) [119]. Resistance is caused by expression of $\beta$-lactamases [129]. Boronic acid mimics the carbonyl group in the $\beta$-lactam ring. The mechanism of action involves a covalent binding of the boron atom with the active site serine hydroxyl group (Figure 25). Vaborbactam inhibits class $A$ and class $C$ serine $\beta$-lactamases [119]. The affinity for the enzyme can be adjusted by modifying the side chain on the boron containing ring [130]. 
<smiles>O=C(O)C[C@H]1CC[C@@H](NC(=O)Cc2cccs2)B(O)O1</smiles>

105

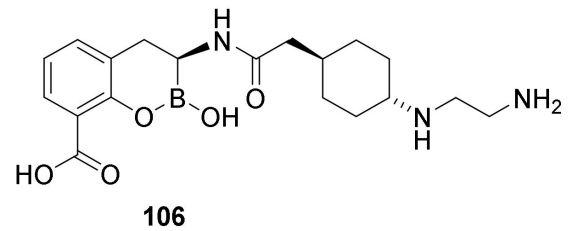

106

Figure 24. Boronic acid $\beta$-lactamase inhibitors. Vaborbactam (105) and taniborbactam (106).<smiles></smiles><smiles>[Z10]OB1B(O[Z10])c2c(CC(NC(=O)CC3CCC(NCCN)CC3)O[Z10])cccc2C1=O</smiles>

Figure 25. Serine- $\beta$-lactamase-varbobactam complex [129] and metallo- $\beta$-lactamase-taniborbactam complex [119].

Taniborbactam (106) is the first serine- $\beta$-lactamase inhibitor, which inhibits all the three groups of serine- $\beta$-lactamases, A, C and D and even some metallo- $\beta$-lactamase inhibitors, group B $[119,120]$. An apparently successful clinical trial 3 randomized double blind study comparing taniborlactam-cefepime versus meropenem is performed [120].

\section{Conclusions and Perspectives}

The observation that the major fall in the death rate caused by infectious diseases occurred before the introduction of antibiotic drugs with improved hygiene and sanitation [1] should not lead to the misconception that these drugs have not revolutionized the treatment of bacterial infections. The first antibiotic drugs, salvarsan and sulfonamides, had a limited spectrum of activity but still enabled physicians to cure previous untreatable diseases. Introduction of $\beta$-lactam antibiotics has significantly improved the armamentarium for treatment to such an extent that today less than $1 \%$ of deaths are caused by of infectious diseases in high income countries $[2,72,123]$. However, development of extended spectrum resistant bacteria threatens the present state of control of infectious diseases [84]. In particular, a rapid spread of carbapenem resistant Pseudomonas aruginosa and extended spectrum resistant $\beta$-lactamase expressing species of Enterobacteriaceae is alarming [21]. In South Europe, $25-50 \%$ of $p$. aeruginosa strains are carbapenem resistant. Similar alarming observations have been made for Acinetobacter baumanii and S. aureus [131]. A meta-analysis has revealed that $14 \%$ of healthy individuals carry extended spectrum resistant $\beta$-lactamase producing bacteria. This number might increase [21]. In 2016 the annual mortality caused by resistant bacteria was estimated to 23,000 persons in the USA [70]. Treatment of patients infected with multi resistant bacteria is time consuming, expensive and risky. An analysis of 1391 patients infected with multi resistant bacteria hospitalized at Chicago Teaching Hospital disclosed (1) an excess duration of hospitalization estimated to between 6.4 to 12.7 days (2) additional costs of USD 18,600-29,000 for each patient (3) a mortality of $6.5 \%$ and (4) social costs of USD 11-15 millions [132]. An estimate predicts that in 2050 extended spectrum resistant bacteria cause 10 million deaths and will drain the society for USD 100 trillion each year [21].

A part of the problem origins in misuse of and overuse of antibiotics in human and veterinary medicine. Use of antibiotics to increase growth rate of livestock should be avoided. Recent estimates suggest that $70 \%$ of antibiotics are used in animals [131]. Public education should prevent use of antibiotics to treat infections caused by virus like common cold. Viral infections are not affected by antibiotics. Sale of antibiotics over the counter might have led to misuse and should be prohibited. Already Alexander Fleming in 1945 in his Nobel lecture warned against the risk of resistance by misuse of antibiotic drugs [131].

Despite spreading resistance only few new antibiotics are currently marketed, as illustrated in Table 1 [133]. 
Table 1. New antibiotic drugs approved by FDA in the period 1983-2012 [133,134].

\begin{tabular}{ccc}
\hline Period & Number & Ref. \\
\hline $1983-1987$ & 16 & {$[133]$} \\
$1988-1992$ & 14 & {$[133]$} \\
$1993-1997$ & 10 & {$[133]$} \\
$1998-2002$ & 7 & {$[133]$} \\
$2003-2007$ & 5 & {$[133]$} \\
$2008-2012$ & 2 & {$[133]$} \\
$2011-2017$ & 8 & {$[134]$} \\
$2014-2020$ & 15 & {$[84]$} \\
\hline
\end{tabular}

The last two entrances are taken from different reference explaining the deviation.

Many multinational pharmaceutical companies have stopped their projects for developing antibiotics $[70,133]$. The vast majority of the drugs approved in the period 2014 to 2020 originated in well-known classes of antibiotics. Some innovative developments are seen in the field of $\beta$-lactamase inhibitors [84]. The poor return of investment compared to other drugs such as drugs for diabetes or cancer is demotivating. The sale of marketed antibiotic drugs the first two years afforded a sale of between USD 20 million (orbactiv, a glycopeptide for treatment of severe infection with Gram-positive bacteria) to USD 80 million (avycaz (Section 9.2)). In contrast, the sale of other medicines varied between USD 600 million (linzess/linacloride for treatment of constipation) and USD 1,500 million (januvia/sitagliptin for treatment of type 2 diabetes). The present spreading of resistance could result in a situation with increased mortality caused by communicative infections. To prevent such a situation the US Congress passed legislation in 2012 to create incentives for developing drugs $[20,84]$. Common for the antibiotic drugs approved in the period 2011 to 2017 is that they all have been marketed by small pharmaceutical companies; even though some of drugs were developed by international companies. Thus, small companies have a niche for developing and marketing antibiotic drugs. The latest marketed drugs are combination therapy combining $\beta$-lactams with $\beta$-lactamase inhibitors e.g., ceftazidime (70) in combination with avibactam $(\mathbf{1 0 3})[120,134]$. No compounds with a new mechanism of action have been marketed.

Beside antibiotics, vaccination is an additional tool to control communicative diseases. The first vaccination was performed in 1796 when Jenner injected lymph from a cow-pox vesicle into a boy. The boy developed a cow-pox pustule and became protected against smallpox [3]. Today vaccination has become an important tool for preventing diseases. It has led to the eradication of smallpox, the elimination of polio from most countries, and the control of other diseases, including diphtheria, tetanus, pertussis, rubella, and hepatitis B [135]. In addition to improving life quality it also saves the society for huge expenses to health care. An outstanding example is the present COVID-19 pandemic. Populations with high immunity because of vaccination carry a much smaller burden than poorly vaccinated populations. Since no person can be vaccinated against all infectious diseases antibiotic drugs always will be an important armamentarium in medicine.

In the fight against malaria, another severe burden for mankind [26], the assumption that man may defeat Nature turned out to be naive. This also is true for the fight against infectious diseases. Nature always fights back. That is why Nature has become so elaborate. The challenge is continuously to develop innovative drugs that keep the pressure from pathogenic organisms at a minimum, even though the return of investment might be poor. Governmental and international institutions and academia have to develop programs to control the spreading of extended spectrum resistance bacteria.

Funding: This research received no external funding.

Institutional Review Board Statement: Not applicable.

Informed Consent Statement: Not applicable. 
Conflicts of Interest: The authors declare no conflict of interest.

\section{References}

1. Koefoed, M. Befolkningsforholdene i Danmark; Statens Stistiske Buerau: Copenhagen, Denmark, 1905.

2. Christensen, G. Døden Skifter Årsag; Dansk Sygeplejehistoriske Museum: Copenhagen, Denmark, $2017 ;$ p. 15.

3. Singer, C.; Underwood, E.A. A Short History of Medicine, 2nd ed.; Clarendon Press: Oxford, UK, 1962.

4. Slavkin, H.C. Biofilms, microbial ecology and Antoni van Leeuwenhoek. J. Am. Dent. Assoc. 1997, 128, 492-495. [CrossRef] [PubMed]

5. Müller, O.F. Animalcula Infusoria Fluviatilia er Marina; Mölleri, T.N., Ed.; Hauniæ: Copenhagen, Denmark, 1786.

6. $\quad$ Pasteur, L. Étude sur le Vin, 2nd ed.; Librairie F. Savy: Paris, France, 1873.

7. Warren, J.R. Unidentified curved bacilli on gastric epithelium in active chronic gastritis. Lancet 1983, 1, 1273. [PubMed]

8. Marshall, B. Unidentified curved bacilli on gastric epithelium in active chronic gastritis. Lancet 1983, 1, $1273-1275$.

9. Marshall, B.J.; Warren, J.R. Unidentified curved bacilli in the stomach of patients with gastritis and peptic ulceration. Lancet 1984, 1, 1311-1314. [CrossRef]

10. Ciacci, C.; Mazzacca, G. The history of Helicobacter pylori: A reflection on the relationship between the medical community and industry. Dig. Liver Dis. 2006, 38, 778-780. [CrossRef]

11. Taylor, L.H.; Latham, S.M.; Woolhouse, M.E. Risk factors for human disease emergence. Philos. Trans. R. Soc. Lond. B Biol. Sci. 2001, 356, 983-989. [CrossRef] [PubMed]

12. Sigerist, H.E. The philosphy of hygiene. Bull. Inst. Hist. Med. 1933, 1, 323-331.

13. Abellán, J. Water supply and sanitation services in modern Europe: Developments in 19th-20th centuries. In Proceedings of the XII International Congress of the Spanish Associations of Ecnonomic History, Salamanaca, Spain, 2-3 February 2017; University of Salamanaca: Salamanaca, Spain, 2017; pp. 1-17.

14. Khalifa, M.; Bidaisee, S. The Importance of Clean Water. Sch. J. Appl. Sci. Res. 2018, 1, 17-20.

15. Atanasov, A.G.; Zotchev, S.B.; Dirsch, V.M.; Supuran, C.; The International Natural Product Sciences Taskforce. Natural products in drug discovery: Advances and opportunities. Nat. Rev. Drug Discovery 2021, 20, 200-216. [CrossRef]

16. Porras, G.; Chassagne, F.; Lyles, J.T.; Marquez, L.; Dettweiler, M.; Salam, A.M.; Samarakoon, T.; Shabih, S.; Farrokhi, D.R.; Quave, C.L. Ethnobotany and the Role of Plant Natural Products in Antibiotic Drug Discovery. Chem. Rev. 2021, 121, 3495-3560. [CrossRef]

17. Newman, D.J.; Cragg, G.M. Natural Products as Sources of New Drugs over the Nearly Four Decades from 01/1981 to 09/2019. J Nat. Prod. 2020, 83, 770-803. [CrossRef]

18. Riethmiller, S. From Atoxyl to Salvarsan: Searching for the magic bullet. Chemotherapy 2005, 51, 234-242. [CrossRef]

19. Waksman, S.A. What is an antibiotic or an antibiotic substance? Mycologia 1947, 39, 565-569. [CrossRef]

20. Watkins, W.J.; Plattner, J.J. Anti-infective drugs through medicinal chemistry: A 50-year retrospective. In 2015 Medicinal Chemistry Reviews; Desai, M.C., Ed.; American Chemical Society: Washington, DC, USA, 2015; Volume 50, pp. $242-282$.

21. Bassetti, M.; Poulakou, G.; Ruppe, E.; Bouza, E.; Van Hal, S.J.; Brink, A. Antimicrobial resistance in the next 30 years, humankind, bugs and drugs: A visionary approach. Intensive Care Med. 2017, 43, 1464-1475. [CrossRef]

22. Marko, V. From Aspitin to Viagara; Springer Nature: Cham, Schwitzerland, 2020.

23. Jones, H.W. Report of a series of cases of syphilis terated by Ehrlich's arsenobenzol at the Walter Reed General Hospital Distict of Columbia. Boston Med. Surg. J. 1911, 164, 381-383. [CrossRef]

24. Lloyd, N.C.; Morgan, H.W.; Nicholson, B.K.; Ronimus, R.S. The composition of Ehrlich's salvarsan: Resolution of a century-old debate. Angew. Chem. Int. Ed. 2005, 44, 941-944. [CrossRef]

25. Schwartz, R.S. Perspective: Paul Ehrlich's magic bullets. N. Engl. J. Med. 2004, 350, 1079-1080. [CrossRef]

26. Christensen, S.B. Natrual Products that Changed Society. Biomedicines 2021, 9, 472. [CrossRef]

27. Lesch, J.E. The First Miracle Drugs. How the Sulfa Drugs Transformed Medicine; Oxford University Press: Oxford, UK, 2007.

28. Domagk, G. Ein Beitrag zur Chemotherapie der bakteriellen Infektionen. Dtsch. Med. Wochenschr. 1935, 61, 250-253. [CrossRef]

29. Klee, P.H.; Römer, H. Pontosil bei Streptokokkenkrankungen. Dtsch. Med. Wochenschr. 1935, 61, 253-255. [CrossRef]

30. Ellis, H. The last year before the dawn of antibiotics. Br. J. Hosp. Med. 2009, 70, 475. [CrossRef] [PubMed]

31. Trefouel, J.; Nitti, F.; Bovet, D. Activité du p-aminophénylsulfamide sur les infectións streptococciques enxpérimentales de la souris du lapin. C. R. Seances Soc. Biol. Ses. Fil. 1935, 120, 756-758.

32. Colebrook, L.; Buttle, G.A.H.; O'Meara, R.A.Q. The mode of action of p-aminobenzenesulfonamide and Prontosil in hæmolytic streptococcal infections. Lancet 1936, 228, 1323-1326. [CrossRef]

33. Fuller, A.T. Is p-aminobenzenesulphonamide the active agent in prontosil therapy? Lancet 1937, 229, 194-198. [CrossRef]

34. Loudon, I. Maternal Care and Maternal Mortality in Britain, 1935-1950. In Death in Childbirth: An International Study of Maternal Care and Maternal Mortality 1800-1950; Loudon, I., Ed.; Oxford University Press: Oxford, UK, 1992; pp. $255-270$.

35. Fildes, P. A rational approach to research in chemotherapy. Lancet 1940, 238, 955-957. [CrossRef]

36. Azevedo-Barbosa, H.; Dias, D.F.; Franco, L.L.; Hawkes, J.A.; Carvalho, D.T. From Antibacterial to Antitumour Agents: A Brief Review on The Chemical and Medicinal Aspects of Sulfonamides. Mini-Rev. Med. Chem. 2020, 20, 2052-2066. [CrossRef]

37. Dewick, P.M. Medicinal Natural Products, 3rd ed.; John Wiley and Sons Ltd.: Chicester, UK, 2009. 
38. Lima, L.M.; Silva, B.N.M.d.; Barbosa, G.; Barreiro, E.J. $\beta$-Lactam antibiotics: An overview from a medicinal chemistry perspective. Eur. J. Med. Chem. 2020, 208, 112829. [CrossRef]

39. Palavecino, E.L. Clinical, Epidemiologic, and Laboratory Aspects of Methicillin-Resistant Staphylococcus aureus Infections. CuttingEdge Technologies and Advancements. In Methicillin-Resistant Staphylococcus aureus (MRSA) Protocols, 3rd ed.; Ji, Y., Ed.; Humana Press: New York, NY, USA, 2020; pp. 1-28.

40. Fleming, A. The antibacterial action of cultures of a Penicillium, with special reference to their use in the isolation of $B$. influenzx. Br. J. Exp. Pathol. 1929, 10, 226-236. [CrossRef]

41. Zaffiri, L.; Gardner, J.; Toledo-Pereyra, L.H. History of antibiotics. From salvarsan to cephalosporins. J. Investig. Surg. 2012, 25, 67-77. [CrossRef]

42. Nayler, J.H.C. Early discoveries in the penicillin series. Trends Biochem. Sci. 1991, 16, 195-197. [CrossRef]

43. Petri, W.A. Penicillins, cephalosporins, and other beta-lactam antibiotics. In Goodman E Gilman's the Pharmacological Basis of Therapeutics, 12th ed.; Brunton, L.L., Ed.; McGraw Hill Medicinal: New York, NY, USA, 2011; pp. 1477-1504.

44. Burton, G.; Osborne, N.F.; Pearson, M.; Southgate, R. The b-Lactam Antibiotics. In Burger's Medicinal Chemistry and Drug Discovery; Wolff, M.E., Ed.; John Wiley \& Sons: New York, NY, USA, 1997; Volume 4, pp. 277-363.

45. Pitts, C.R.; Lectka, T. Chemical Synthesis of $\beta$-Lactams: Asymmetric Catalysis and Other Recent Advances. Chem. Rev. 2014, 114, 7930-7953. [CrossRef]

46. Schrøder, P. Fra Løvens Kemiske Fabrik til Leo Pharma A/S. Theriaca 2005, 36, 27-118.

47. Chemistry of Penicilin. Nature 1945, 156, 766-767. [CrossRef]

48. Council T.C.o.M.R.a.T.M.R. Chemistry of Penicillin. Science 1945, 102, 627-629.

49. Nicolaou, K.C.; Snyder, S.A. Chasing molecules that were never there: Misassigned natural products and the role of chemical synthesis in modern structure elucidation. Angew. Chem. Int. Ed. 2005, 44, 1012-1044. [CrossRef]

50. Hodgkin, D.C. X-ray analysis of the structure of penicillin. Adv. Sci. 1949, 6, 85-89.

51. Woodward, R.B. Penems and related substances. Philos. Trans. R. Soc. Lond. Ser. B 1980, 289, 239-250.

52. Fisher, J.F.; Mobashery, S. b-Lactams against the Fortress of the Gram-Positive Staphylococcus aureus Bacterium. Chem. Rev. 2021, 121, 3412-3463. [CrossRef]

53. Rahman, M.; Pyle, D.J.; Bisz, E.; Dziuk, B.; Ejsmont, K.; Lalancette, R.; Wang, Q.; Chen, H.; Szostak, R.; Szostak, M. Evaluation of Cyclic Amides as Activating Groups in N-C Bond Cross-Coupling: Discovery of N-Acyl- $\delta$-valerolactams as Effective Twisted Amide Precursors for Cross-Coupling Reactions. J. Org. Chem. 2021, 86, 10455-10466. [CrossRef]

54. Lejon, S.; Ellis, J.; Valegard, K. The Last Step in Cephalosporin C Formation Revealed: Crystal Structures of Deacetylcephalosporin C Acetyltransferase from Acremonium chrysogenum in Complexes with Reaction Intermediates. J. Mol. Biol. 2008, 377, 935-944. [CrossRef]

55. Rolinson, G.N. Forty years of $\beta$-lactam research. J. Antimicrob. Chemother. 1998, 41, 589-603. [CrossRef] [PubMed]

56. Batchelor, F.R.; Doyle, F.P.; Nayler, J.H.C.; Rolinson, G.N. Synthesis of penicillin-6-aminopenicillanic acid in penicillin fermentations. Nature 1959, 183, 257-258. [CrossRef] [PubMed]

57. Nayler, J.H.C. Semi-synthetic approaches to novel penicillins. Trends Biochem. Sci. 1991, 16, 234-237. [CrossRef]

58. Wang, D.Y.; Abboud, M.I.; Markoulides, M.S.; Brem, J.; Schofield, C.J. The road to avibactam: The first clinically useful non- $\beta$ lactam working somewhat like a $\beta$-lactam. Future Med. Chem. 2016, 8, 1063-1084. [CrossRef]

59. Tipper, D.J.; Strominger, J.L. Mechanism of action of penicillins; a proposal based on their structural similarity to acyl-D-alanyl-Dalanine. Proc. Natl. Acad. Sci. USA 1965, 54, 1133-1141. [CrossRef]

60. Oliva, M.; Dideberg, O.; Field, M.J. Understanding the acylation mechanisms of active-site serine penicillin-recognizing proteins: A molecular dynamics simulation study. Proteins Struct. Funct. Genet. 2003, 53, 88-100. [CrossRef]

61. Boehme, E.H.W.; Applegate, H.E.; Toeplitz, B.; Dolfini, J.E.; Gougoutas, J.Z. 6-Methyl penicillins and 7-methyl cephalosporins. J. Amer. Chem. Soc. 1971, 93, 4324-4326. [CrossRef]

62. Sakaguchi, K.i.; Murao, S. A new enzyme, penicillin-amidase. Preliminary. Nippon Nogei Kagaku Kaishi 1950, 23, 411. [CrossRef]

63. Williamson, G.M.; Morrison, J.K.; Stevens, K.J. A new synthetic penicillin PA-248. Lancet 1961, 1, 847-850. [CrossRef]

64. Nagley, M. Clinical use of a new synthetic penicillin: PA-248. Lancet 1961, 1, 851. [CrossRef]

65. Peter, G. Streptococcal pharyngitis: Current therapy and criteria for evaluation of new agents. Clin. Infect. Dis. 1992, 14 (Suppl. S2), S218-S223. [CrossRef]

66. Fischbach, M.A.; Walsh, C.T. Antibiotics for Emerging Pathogens. Science 2009, 325, 1089-1093. [CrossRef]

67. Rolinson, G.N.; Geddes, A.M. The 50th anniversary of the discovery of 6-aminopenicillanic acid (6-APA). Int. J. Antimicrob. Agents 2007, 29, 3-8. [CrossRef]

68. Nikaido, H. Antibiotic resistance caused by Gram-negative multidrug efflux pumps. Clin. Infect. Dis. 1998, 27 (Suppl. S1), S32-S41. [CrossRef]

69. Abraham, E.P.; Chain, E. An enzyme from bacteria able to destroy penicillin. Nature 1940, 146, 837. [CrossRef]

70. Ogawara, H. Self-resistance in Streptomyces, with special reference to $\beta$-lactam antibiotics. Molecules 2016, 21, 605. [CrossRef]

71. Anderson, E.S.; Datta, N. Resistance to Penicillins and its transfer in enterobacteriaceae. Lancet 1965, 1, 407-409. [CrossRef]

72. Ding, Y.; Li, Z.; Xu, C.; Qin, W.; Wu, Q.; Wang, X.; Cheng, X.; Li, L.; Huang, W. Fluorogenic Probes/Inhibitors of $\beta$-Lactamase and their Applications in Drug-Resistant Bacteria. Angew. Chem. Int. Ed. 2021, 60, 24-40. [CrossRef] 
73. D'Costa, V.M.; King, C.E.; Kalan, L.; Morar, M.; Sung, W.W.L.; Schwarz, C.; Froese, D.; Zazula, G.; Calmels, F.; Debruyne, R.; et al. Antibiotic resistance is ancient. Nature 2011, 477, 457-461. [CrossRef]

74. Ambler, R.P. The structure of $\beta$-lactamases. Philos. Trans. R. Soc. Lond. Ser. B 1980, 289, 321-331.

75. Datta, N.; Kontomichalou, P. Penicillinase synthesis controlled by infectious R factors in Enterobacteriaceae. Nature 1965, 208, 239-241. [CrossRef] [PubMed]

76. Cullmann, W.; Dick, W. Induction potency of various beta-lactam derivatives in gram-negative rods. Chemotherapy 1989, 35, 43-53. [CrossRef] [PubMed]

77. Davies, D.T.; Everett, M. Designing Inhibitors of $\beta$-Lactamase Enzymes to Overcome Carbapenem Resistance in Gram-Negative Bacteria. Acc. Chem. Res. 2021, 54, 2055-2064. [CrossRef] [PubMed]

78. De Araujo Viana Marques, D.; Machado, S.E.F.; Ebinuma, V.C.S.; de Albuquerque Lima Duarte, C.; Converti, A.; Porto, A.L.F. Production of $\beta$-lactamase inhibitors by Streptomyces species. Antibiotics 2018, 7, 61. [CrossRef]

79. Doyle, F.P.; Hardy, K.; Nayler, J.H.C.; Soulal, M.J.; Stove, E.R.; Waddington, H.R.J. Derivatives of 6-aminopenicillanic acid. III. 2,6-Dialkoxybenzoyl derivatives. J. Chem. Soc. 1962, 1453-1458. [CrossRef]

80. Moriyama, Y.; Ishikane, M.; Mezaki, K.; Ohmagari, N. Comparison of penicillins (penicillin G and ampicillin) and cefazolin as a definitive therapy against penicillin-susceptible Staphylococcus aureus (PSSA) bacteremia in Japan: A retrospective cohort study. J. Infect. Chemother. 2020, 26, 358-362. [CrossRef]

81. Sanders, C.C.; Sanders, W.E., Jr. Beta-Lactam resistance in gram-negative bacteria: Global trends and clinical impact. Clin. Infect. Dis. 1992, 15, 824-839. [CrossRef]

82. Baldwin, J.E.; Urban, F.J.; Cooper, R.D.; Jose, F.L. Direct 6-methoxylation of penicillin derivatives. A convenient pathway to substituted -lactam antibiotics. J. Am. Chem. Soc. 1973, 95, 2401-2403. [CrossRef]

83. Basker, M.J.; Edmondson, R.A.; Knott, S.J.; Ponsford, R.J.; Slocombe, B.; White, S.J. In vitro antibacterial properties of BRL 36650, a novel $6 \alpha$-substituted penicillin. Antimicrob. Agents Chemother. 1984, 26, 734-740. [CrossRef]

84. Brown, D.G.; Wobst, H.J. A Decade of FDA-Approved Drugs (2010-2019): Trends and Future Directions. J. Med. Chem. 2021, 64, 2312-2338. [CrossRef]

85. Murakami, M.; Takahashi, K.; Isaka, I.; Kawahara, N.; Horiguchi, H.; Murakami, Y.; Sakamoto, N.; Ozasa, T.; Kashiwagi, T.; Nakano, K.; et al. New Oxymethylester Derivatives of Penicillin and Cephalosporin. German Patent DE2228670A1, 11 January 1973.

86. Roholt, K.; Nielsen, B.; Kristensen, E. Clinical pharmacology of pivampicillin. Antimicrob. Agents Chemother. 1974, 6, 563-571. [CrossRef]

87. Rose, S.J.; Stokes, T.C.; Patel, S.; Cooper, M.B.; Betteridge, D.J.; Payne, J.E. Carnitine deficiency associated with long-term pivampicillin treatment: The effect of a replacement therapy regime. Postgrad. Med. J. 1992, 68, 932-934. [CrossRef]

88. Clayton, J.P.; Cole, M.; Elson, S.W.; Ferres, H. BRL.8988 (Talampicillin), a well-absorbed oral form of ampicillin. Antimicrob. Agents Chemother. 1974, 5, 670-671. [CrossRef]

89. Tan, J.S.; Salstrom, S.J. Bacampicillin, ampicillin, cephalothin and cephapirin levels in human blood and interstitial fluid. Antimicrob. Agents Chemother. 1979, 15, 510-512. [CrossRef]

90. Omata, H.; Komiya, M.; Akimoto, Y.; Kaneko, K.; Fujii, A. Ampicillin concentrations in human serum and oral tissues following a single oral administration of lenampicillin. Chemotherapy 1994, 42, 172-176.

91. Abraham, E.P.; Loder, P.B. Cephalosporin C. In Cephalosporins and Penicillins; Flynn, E.H., Ed.; Princeton University Press: London, UK, 1972; pp. 1-26.

92. Newton, G.G.F.; Abraham, E.P. Cephalosporin C, a new antibiotic containing sulfur and D- $\alpha$-aminoadipic acid. Nature 1955, 175, 548. [CrossRef]

93. Abraham, E.P.; Newton, G.G.F. Structure of cephalosporin C. Biochem. J. 1961, 79, 377-393. [CrossRef]

94. Hodgkin, D.C.; Maslen, E.N. The X-ray analysis of the structure of cephalosporin C. Biochem. J. 1961, 79, 393-402. [CrossRef]

95. Morin, R.B.; Jackson, B.G.; Mueller, R.A.; Lavagnino, E.R.; Scanlon, W.B.; Andrews, S.L. Chemistry of cephalosporin antibiotics. III. Chemical correlation of penicillin and cephalosporin antibiotics. J. Am. Chem. Soc. 1963, 85, 1896-1897. [CrossRef]

96. Lucinova, E.; Welward, L.; Frimm, R.; Kosalko, R.; Sokol, M. 7-Aminocephalosporanic Acid. Czech Patent CS193181B1, 31 October 1979 .

97. Hardianto, D.; Royani, J.I.; Safarrida, A. Cephalosporin C acylase from microbes for one-step enzymatic transformation of cephalosporin C to 7-aminocephalosporanic acid. J. Pure Appl. Microbiol. 2016, 10, 2495-2499. [CrossRef]

98. Masoud, M.S.; Ali, A.E.; Nasr, N.M. Chemistry, classification, pharmacokinetics, clinical uses and analysis of beta lactam antibiotics: A review. J. Chem. Pharm. Res. 2014, 6, 28-58.

99. Mehta, D.; Sharma, A.K. Cephalosporins: A Review on Imperative Class of Antibiotics. Inventi Rapid Mol. Pharmacol. 2016, 2016, 17877.

100. Ge, Y.; Maynard, D.; Rickert, D.E. Comparative pharmacokinetics of ceftaroline in rats, rabbits, and monkeys following a single intravenous or intramuscular injection. Antimicrob. Agents Chemother. 2010, 54, 912-914. [CrossRef]

101. Papp-Wallace, K.M.; Endimiani, A.; Taracila, M.A.; Bonomo, R.A. Carbapenems: Past, present, and future. Antimicrob. Agents Chemother. 2011, 55, 4943-4960. [CrossRef]

102. Kropp, H.; Sundelof, J.G.; Hajdu, R.; Kahan, F.M. Metabolism of thienamycin and related carbapenem antibiotics by the renal dipeptidase, dehydropeptidase-I. Antimicrob. Agents Chemother. 1982, 22, 62-70. [CrossRef] 
103. Breilh, D.; Texier-Maugein, J.; Allaouchiche, B.; Saux, M.-C.; Boselli, E. Carbapenems. J. Chemother. 2013, 25, 1-17. [CrossRef]

104. Fukasawa, M.; Sumita, Y.; Harabe, E.T.; Tanio, T.; Nouda, H.; Kohzuki, T.; Okuda, T.; Matsumura, H.; Sunagawa, M. Stability of meropenem and effect of $1 \beta$-methyl substitution on its stability in the presence of renal dehydropeptidase I. Antimicrob. Agents Chemother. 1992, 36, 1577-1579. [CrossRef] [PubMed]

105. Bouffard, F.A.; Johnston, D.B.R.; Christensen, B.G. Thienamycin total synthesis. 1. Synthesis of azetidinone precursors of ( \pm )-thienamycin and its stereoisomers. J. Org. Chem. 1980, 45, 1130-1135. [CrossRef]

106. Schmitt, S.M.; Johnston, D.B.R.; Christensen, B.G. Thienamycin total synthesis. 2. Model studies-synthesis of a simple 2(alkylthio)carbapen-2-em. J. Org. Chem. 1980, 45, 1135-1142. [CrossRef]

107. Schmitt, S.M.; Johnston, D.B.R.; Christensen, B.G. Thienamycin total synthesis. 3. Total synthesis of $( \pm)$-thienamycin and ( \pm )-8-epithienamycin. J. Org. Chem. 1980, 45, 1142-1148. [CrossRef]

108. Kametani, T.; Huang, S.-P.; Yokohama, S.; Suzuki, Y.; Ihara, M. Studies on the syntheses of heterocyclic compounds. 800. A formal total synthesis of $( \pm)$-thienamycin and a $( \pm)$-decysteaminylthienamycin derivative. J. Am. Chem. Soc. 1980, 102, 2060-2065. [CrossRef]

109. Berks, A.H. Preparations of two pivotal intermediates for the synthesis of $1-\beta$-methyl carbapenem antibiotics. Tetrahedron 1996, 52, 331-375. [CrossRef]

110. El-Gamal, M.I.; Brahim, I.; Hisham, N.; Aladdin, R.; Mohammed, H.; Bahaaeldin, A. Recent updates of carbapenem antibiotics. Eur. J. Med. Chem. 2017, 131, 185-195. [CrossRef]

111. Cotroneo, N.; Rubio, A.; Critchley, I.A.; Pillar, C.; Pucci, M.J. In vitro and in vivo characterization of tebipenem, an oral carbapenem. Antimicrob. Agents Chemother. 2020, 64, e02240-19. [CrossRef]

112. Han, H.; Liu, J.; Hu, L.; Wu, Y. Synthesis of Faropenem. Zhongguo Yiyao Gongye Zazhi 2001, 32, 339-341.

113. Volkmann, R.A.; Kelbaugh, P.R.; Nason, D.M.; Jasys, V.J. 2-Thioalkyl penems: An efficient synthesis of sulopenem, a (5R,6S)-6(1(R)-hydroxyethyl)-2-[(cis-1-oxo-3-thiolanyl)thio]-2-penem antibacterial. J. Org. Chem. 1992, 57, 4352-4361. [CrossRef]

114. Woodcock, J.M.; Andrews, J.M.; Brenwald, N.P.; Ashby, J.P.; Wise, R. The in-vitro activity of faropenem, a novel oral penem. J. Antimicrob. Chemother. 1997, 39, 35-43. [CrossRef]

115. Schurek, K.N.; Wiebe, R.; Karlowsky, J.A.; Rubinstein, E.; Hoban, D.J.; Zhanel, G.G. Faropenem: Review of a new oral penem. Expert Rev. Anti-Infect. Ther. 2007, 5, 185-198. [CrossRef]

116. Imada, A.; Kitano, K.; Kintaka, K.; Muroi, M.; Asai, M. Sulfazecin and isosulfazecin, novel $\beta$-lactam antibiotics of bacterial origin. Nature 1981, 289, 590-591. [CrossRef]

117. Sykes, R.B.; Bonner, D.P.; Bush, K.; Georgopapadakou, N.H.; Wells, J.S. Monobactams-monocyclic $\beta$-lactam antibiotics produced by bacteria. J. Antimicrob. Chemother. 1981, 8, 1-16. [CrossRef]

118. Ramsey, C.; MacGowan, A.P. A review of the pharmacokinetics and pharmacodynamics of aztreonam. J. Antimicrob. Chemother. 2016, 71, 2704-2712. [CrossRef] [PubMed]

119. Jalde, S.S.; Choi, H.K. Recent advances in the development of $\beta$-lactamase inhibitors. J. Microbiol. 2020, 58, 633-647. [CrossRef] [PubMed]

120. Yahav, D.; Giske, C.G.; Graematniece, A.; Abodakpi, H.; Tam, V.H.; Leibovici, L. New $\beta$-Lactam- $\beta$-Lactamase Inhibitor Combinations. Clin. Microbiol. Rev. 2021, 34, e00115. [CrossRef] [PubMed]

121. Brown, A.G.; Butterworth, D.; Cole, M.; Hanscomb, G.; Hood, J.D.; Reading, C.; Rolinson, G.N. Naturally occurring $\beta$-lactamase inhibitors with antibacterial activity. J. Antibiot. 1976, 29, 668-669. [CrossRef]

122. Howarth, T.T.; Brown, A.G.; King, T.J. Clavulanic acid, a novel $\beta$-lactam isolated from Streptomyces clavuligerus; X-ray crystal structure analysis. J. Chem. Soc. Chem. Commun. 1976, 266-267. [CrossRef]

123. Buynak, J.D. Understanding the longevity of the $\beta$-lactam antibiotics and of antibiotic/ $\beta$-lactamase inhibitor combinations. Biochem. Pharmacol. 2006, 71, 930-940. [CrossRef]

124. Harada, S.; Tsubotani, S.; Hida, T.; Ono, H.; Okazaki, H. Structure of lactivicin, an antibiotic having a new nucleus and similar biological activities to $\beta$-lactam antibiotics. Tetrahedron Lett. 1986, 27, 6229-6232. [CrossRef]

125. Nozaki, Y.; Katayama, N.; Ono, H.; Tsubotani, S.; Harada, S.; Okazaki, H.; Nakao, Y. Binding of a non- $\beta$-lactam antibiotic to penicillin-binding proteins. Nature 1987, 325, 179-180. [CrossRef]

126. Holzgrabe, U. Lactivicin-An antibiotic against penicillin-resistant pneumococci. Pharm. Unserer Zeit 2007, 36, 421-423. [CrossRef]

127. Vazquez, J.A.; Gonzalez Patzan, L.D.; Stricklin, D.; Duttaroy, D.D.; Kreidly, Z.; Lipka, J.; Sable, C. Efficacy and safety of ceftazidimeavibactam versus imipenem-cilastatin in the treatment of complicated urinary tract infections, including acute pyelonephritis, in hospitalized adults: Results of a prospective, investigator-blinded, randomized study. Curr. Med. Res. Opin. 2012, 28, $1921-1931$. [CrossRef]

128. Vazquez-Ucha, J.C.; Rodriguez, D.; Lasarte-Monterrubio, C.; Lence, E.; Arca-Suarez, J.; Maneiro, M.; Gato, E.; Perez, A.; MartinezGuitian, M.; Juan, C.; et al. 6-Halopyridylmethylidene Penicillin-Based Sulfones Efficiently Inactivate the Natural Resistance of Pseudomonas aeruginosa to $\beta$-Lactam Antibiotics. J. Med. Chem. 2021, 64, 6310-6328. [CrossRef]

129. Dhillon, S. Meropenem/Vaborbactam: A Review in Complicated Urinary Tract Infections. Drugs 2018, 78, 1259-1270. [CrossRef]

130. Morandi, S.; Morandi, F.; Caselli, E.; Shoichet, B.K.; Prati, F. Structure-based optimization of cephalothin-analogue boronic acids as $\beta$-lactamase inhibitors. Bioorg. Med. Chem. 2008, 16, 1195-1205. [CrossRef]

131. Barriere, S.L. Clinical, economic and societal impact of antibiotic resistance. Expert Opin. Pharmacother. 2015, 16, 151-153. [CrossRef] 
132. Roberts, R.R.; Hota, B.; Ahmad, I.; Scott, R.D., 2nd; Foster, S.D.; Abbasi, F.; Schabowski, S.; Kampe, L.M.; Ciavarella, G.G.; Supino, M.; et al. Hospital and societal costs of antimicrobial-resistant infections in a Chicago teaching hospital: Implications for antibiotic stewardship. Clin. Infect. Dis. 2009, 49, 1175-1184. [CrossRef]

133. Boucher, H.W.; Talbot, G.H.; Benjamin, D.K., Jr.; Bradley, J.; Guidos, R.J.; Jones, R.N.; Murray, B.E.; Bonomo, R.A.; Gilbert, D. $10 \times$ '20 Progress-Development of new drugs active against gram-negative bacilli: An update from the Infectious Diseases Society of America. Clin. Infect. Dis. 2013, 56, 1685-1694. [CrossRef]

134. Fernandes, P.; Martens, E. Antibiotics in late clinical development. Biochem. Pharmacol. 2017, 133, 152-163. [CrossRef]

135. Remy, V.; Largeron, N.; Quilici, S.; Carroll, S. The economic value of vaccination: Why prevention is wealth. J. Mark. Access Health Policy 2015, 3, 1. [CrossRef] 